\title{
Performance Characteristics of Ring-Cusp Thrusters With Xenon Propellant
}

\section{LIRRARY COPY}

Michael J. Patterson

Lewis Research Center

Cleveland, Ohio
SEP 80

LANGLEY RESEARCH CENTER

LURARY, NASA'

HALOTON, YIRGIUIA

Prepared for the 22nd Joint Propulsion Conference cosponsored by the AIAA, ASME, SAE, and ASEE Huntsville, Alabama, June 16-18, 1986 


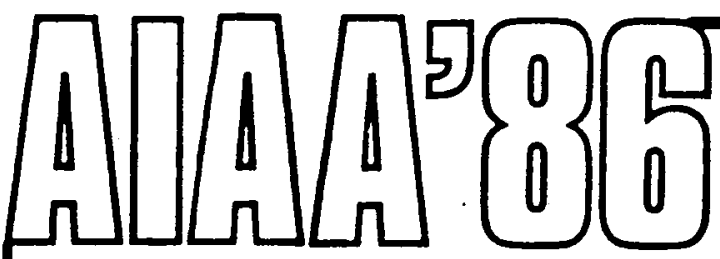

AIAA-86-1392

Performance Characteristics of

Ring-Cusp Thrusters With

Xenon Propellant

Michael J. Patterson, NASA Lewis

Research Center, Cleveland, $\mathrm{OH}$

\section{AIAA/ASME/SAE/ASEE 22nd Joint Propulsion Conference}

June 16-18, 1986/Huntsville, Alabama 


\title{
PERFORMANCE CHARACTERISTICS OF RING-CUSP THRUSTERS
}

\author{
WITH XENON PROPELLANT \\ Michael J. Patterson \\ National Aeronautics and Space Administration \\ Lewis Research Center \\ Cleveland, Ohio 44135
}

\section{SUMMARY}

The performance characteristics and operating envelope of several $30-\mathrm{cm}$ ring-cusp ion thrusters with xenon propellant were investigated. Results indicate a strong performance dependence on the discharge chamber boundary magnetic fields and resultant distribution of electron currents. Significant improvements in discharge chamber performance over J-series divergent-field thrusters was achieved for large throttling ranges, which translate into reduced cathode emission currents and reduced power dissipation which should be of significant benefit for operation at thruster power levels in excess of $10 \mathrm{~kW}$.

Mass spectrometry of the ion beam was documented for both the ring-cusp and $\mathrm{J}$-series thrusters with xenon propellant for determination of overall thruster efficiency, and lifetime. Based on the lower centerline values of doubly charged ions in the ion beam and the lower operating discharge voltage, the screen grid erosion rate of the ring-cusp thruster is expected to be lower than the divergent-field J-series thruster by a factor of 2 .

\section{INTRODUCTION}

Recent studies have indicated that ion thrusters are an excellent candidate for orbit-transfer applications (refs. 1 and 2). Because of their demonstrated range of high specific impulse at superior thruster efficiencies, ion thrusters can deliver significant payload gains over other forms of electric and chemical propulsion for these and other mission scenarios (ref. 3), while providing large cost savings as a consequence of the reduction in orbit-transfer propellant required to be raised to low-earth orbit (ref. 4).

Based on methodology developed by Byers and colleagues (refs. 5 and 6), more recent efforts have been conducted to define the ion thruster propulsion subsystem for the proposed SP-100 nuclear power reference mission (ref. 7), as well as a 21 st-century manned-mars-mission (ref. 8), involving input power levels to the propulsion subsystem in excess of $270 \mathrm{~kW}$ and $3 \mathrm{MW}$, respectively. These and other studies (refs. 3 and 9) indicate the need for the development of larger, higher power xenon ion thrusters to reduce the system complexity and numbers of thrusters required to accomplish these missions.

The development of larger and higher power fon thrusters beyond the $30-\mathrm{cm}$ diameter $10-\mathrm{kW}$ level demonstrated with the J-series divergent magnetic field thruster (ref. 3), necessitates reducing the discharge power per beam ampere, or ion beam production cost, below values demonstrate for the baseline J-series thruster with xenon propellant (ref. 10), while maintaining high values of 
propellant efficiency. Reduced discharge power requirements benefit the thruster thermal design by increasing the permissible extracted beam current for a fixed grid temperature (refs. 11 and 12), by reducing the cathode emission current (and consequently cathode self-heating for a fixed beam current), and by decreasing the dissipated power requirements per thruster.

Recently, a 30-cm diameter magnetic multipole ring-cusp ion thruster configuration was developed by Sovey (ref. 13) which demonstrated a marked increase in discharge chamber performance, a reduction in the operating ion beam production cost, over conventional divergent magnetic field thrusters with inert gas propellants. The impact of this thruster technology on high power applications is significant. For the selected ion thruster operating point of 4710 sec specific impulse at $0.94 \mathrm{~N}$ thrust for the proposed SP-100 reference mission (ref. 7), an array of $1050-\mathrm{cm}$ diameter 30-kW divergent field thrusters would have to dissipate greater than $23 \mathrm{~kW}$ of power. Incorporating ring-cusp discharge chamber technology would reduce this level to below $14 \mathrm{~kW}$. Each divergent-field thruster in the array would require cathode emission current levels in excess of $70 \mathrm{~A}$, whereas ring-cusp thrusters would reduce this level to below 45 A per thruster.

Subsequent efforts have been conducted to characterize the performance of a single ring-cusp magnetic configuration (scaled to the best geometry demonstrated by Sovey), with mercury propellant over a range of throttiing conditions (ref. 14). Performance for this ring-cusp magnetic configuration with xenon propellant was documented by Poeschel (ref. 15), but was restricted to a single operating point at $2.3 \mathrm{~kW}$ power level. Other performance data documented for ring-cusp thrusters with xenon propellant has generally been limited to a single magnetic configuration for thruster input power levels of $2 \mathrm{~kW}$ or less (refs. 16 and 17). Further, aside from the original ring-cusp thruster investigation (ref. 13), there has been no documented mass spectrometry conducted to detect singly and multiply charged beam ions for ring-cusp thrusters with xenon propellant. This information is critical to assessing the thrustto-power levels and thruster lifetime; multiply charged ions constitute a thrust-loss (ref. 18), and they cause excessive sputter-erosion of thruster components, a major life-limiting phenomenon (refs. 19 to 21). There has also been no beam mass spectrometry conducted for the baseline J-series divergent magnetic field thruster with xenon propellant. Based on the limited scope of the ring-cusp thruster investigations with xenon propellant and the lack of mass spectrometry data for the ring-cusp and J-series thrusters, a program was initiated to address a performance and iifetime comparison of the two types of thrusters.

This paper outlines recent data on the performance and operating characteristics of several $30-\mathrm{cm}$ magnetic multipole ring-cusp thrusters with xenon propellant. This was with the intent of studying new magnetic configurations with comparable or improved performance to that documented by Sovey (ref. 13), which would operate stably over a wide range of operating conditions for measurement of multiply charged beam ions. The scope of the investigation included three basic objectives. The first objective focused on assessing the performance characteristics and operating envelope of several ring-cusp thrusters over a range of input power levels up to $8 \mathrm{~kW}$ to define a baseline ion beam production cost and magnetic geometry. This work involved analyzing the performance impact of modifications to the configuration and strength of the 
boundary magnetic fields in the discharge chamber. This has been the experimental approach for most thruster studies to date. As was concluded by Brophy (ref. 22), the dominant mechanisms affecting thruster performance are the utilization of primary electrons and the extracted ion fraction, both of which are principally dependent on the magnetic field configuration and magnetic field strength in the discharge chamber. The second objective focused on conducting ion beam mass spectrometry of the ring-cusp and J-series thrusters with xenon propellant to determine the multiply charged ion content, assess thruster lifetime, and determine overall thruster efficiency. The final objective was to provide a significant data base to assist in comparing the operating characteristics of the ring-cusp and J-sertes divergent-field thrusters with xenon propellant.

\section{APPARATUS}

\section{Thrusters}

The ring-cusp thruster (ref. 13) differs markediy from the conventional divergent-field J-series thruster (ref. 23). The principle difference is the configuration and strength of the magnetic field employed to contain the primary electrons. Schematics of the two types of thrusters are shown in figures 1 (a) and (b). The divergent-field J-series thruster was originaliy developed for a Solar Electric Propulsion stage (ref. 24). The field strengths in the ring-cusp thruster ranges from about $20 \mathrm{mT}$ at the cathode tip to less than $0.5 \mathrm{mT}$ at the ion-extraction plane, whereas the peak J-series field is on the order of only 0.6 to $0.7 \mathrm{mT}$. The magnetic field for the ring-cusp thruster is created by samarium-cobalt magnets arranged in rings of alternating polarity located along the back and sides of the discharge chamber. A diverging field at the cathode, produced by an Ainico cylindrical magnet mounted on the cathode assembly, provides magnetic-coupling to the discharge chamber walls. A downstream pole piece terminates the magnetic field lines upstream of the ion optics. The ring-cusp thruster is operated with the entire discharge chamber, including the cylindrical shel1, backplate, and downstream pole piece, at anode potential. The samarium-cobalt magnets are attached directly to the discharge chamber walls, providing magnetic field lines, at the field-cusps, terminating on anode potential surfaces. In the J-series thruster. Alnico magnets are located axially around the anode shell, coupling from the cathode to downstream pole pieces to create a divergent field.

The basic design features of the ring-cusp configuration - the strong multicusp boundary field with an anode shell, the diverging field in the cathode region, and the downstream anode pole plece - are all employed to reduce the ion wall losses in the discharge chamber and enhance the forward ion flux toward the grid system.

The baseline magnetic field configuration used in this investigation was designated configuration number 1 . This configuration operated at the lowest ion beam production cost (at high propellant efficiencies) of those thrusters investigated in reference 13. Figure 2 shows the position and polarity of the magnet rings for configuration number 1 . Twelve subsequent field configurations were investigated and the parameters of each configuration are presented in table I. Table II outlines the configuration changes of the twelve geometries from the baseline thruster. These were achieved by changing the magnetic field strength at the ring-cusps (by layering the samarium-cobalt magnets) 
and/or changing the field strength at the cathode orifice (by axially repositioning the cathode magnet). Aside from pole piece ring number 6 , no changes were made in the periodicity or number of magnet rings in the discharge chamber. The magnet ring numbers referenced in tables II and III correspond to those indicated in figure 2.

The J-series thruster (J-8) also used in this investigation is described in references 10 and 25 and was operated with the use of a single piece $4.1-\mathrm{cm}$ diameter magnetic baffle instead of the standard three piece tantalum clad 5.6-cm diameter baffle. The modifled J-series thruster referred to in this investigation is the J-8 thruster operated with the $4.1-\mathrm{cm}$ diameter baffle removed.

The cathodes used in this investigation were constructed of tantalum or molybdenum-rhenium tubing, with a 2 percent thoriated tungsten tip which was electron beam welded to one end of the tube. The other end of the tube was connected to the cathode propellant feed. A tantalum sheathed heater was friction fitted to the forward end of the cathode for thermal conditioning of the inserts. The inserts consisted of a barium impregnated porous tungsten cylinder, which was placed inside the cathode tube and fitted immediately behind the cathode tip. Several replacements in the cathode body tubes and tips were required during this investigation because of damage sustained during high emission current operation. The cathodes did not have sufficient area for radiation (ref. 23) for sustained high current operation. The dimensions of the cathode body tubes and tips used in the thruster configurations are presented in table I.

The grid specifications for the ion extraction assemblies used for ring cusp and $\mathrm{j}$-series thrusters are presented in table III. The screen and acce1erator grid open area fractions for the ring-cusp and J-series ion optics were 0.76 and 0.27 , respectively. The modified J-series thruster was operated with ion optics having screen and acceleration grid open area fractions of 0.67 and 0.23 , respective1y.

\section{Mass Spectrometer}

The $E X B$ mass spectrometer used in this investigation was fabricated by Loral EOS (ref. 17), and is similar to that described in reference 18 . The spectrometer was located approximately $29 \mathrm{-cm}$ downstream of the thruster grid system and was used to detect singly and multiply charged xenon ions.

\section{Facility}

The testing of the J-series and the ring-cusp thrusters presented here was conducted at the NASA Lewis Research Center Tank 5 facility. The vacuum tank is 4.6 by $19.2 \mathrm{~m}$ long and has a base pressure (without propellant gas flow) of about $2 \times 10^{-6}$ torr. The operating factitity pressures were generally less than $2.5 \times 10^{-5}$ torr for xenon flow rates below $100 \mathrm{sccm}$.

Rapid access to the thrusters was provided by two $0.9 \mathrm{~m}$ dlameter ports equipped with gate valves. 
Power Supplites

Sixty Hertz input laboratory power supplies were used. The cathode and neutralizer heaters were powered with alternating current while the discharge, magnetic baffle ( $J$-series thruster), and cathode keeper supplies had full wave, single phase, rectified outputs. The discharge supply had a $100 \mathrm{~V} / 100$. A output operated in a current limited mode. The high voltage screen and accelerator grid supplies were high capacity, three phase, full wave bridge rectified design.

\section{Propellant Feed System}

Research grade xenon (>99.99 percent purity) was used in this investigation. The main, cathode, and neutralizer flow rates were closed-loop controlled using flow meters and plezoelectric flow controllers. The flow rates were measured with digital readout mass flow rate transducers which were calibrated using volume displacement methods.

\section{PROCEDURE}

\section{Thruster Operation}

Each thruster was installed in the Tank 5 facility at least $24 \mathrm{hr}$ prior to thruster startup. When the thruster had been exposed to atmosphere for a configuration change, the cathode, main, and neutralizer propellant lines were purged with argon gas for approximately $20 \mathrm{~min}$ to flush air from the system to prevent poisoning of the cathode inserts. The cathode and neutralizer inserts were conditioned by heating the cathode with $5 \mathrm{~A}$ through the tantalum sheathed heater. After the cathode discharges were ignited and the propellant flows were reduced to near-operating levels, the high voltage was applied to the grid system to extract an ion beam. Typical screen and accelerator grid voltages were +1400 and $-500 \mathrm{~V}$, respectively. The total voltage between the grids at a given beam current was set so that the accelerator grid impingement current was less than 2 percent of the beam current. A performance curve of the thruster was then generated to characterize the power and propellant efficiencies of the magnetic field configuration. This was accomplished by adjusting the reference signal for the current limited discharge current. For each value of increasing. discharge current, an ion beam production cost and propellant efficiency were calculated.

The discharge chamber performance presented for the ring-cusp and J-series thruster were corrected to account for gas ingestion.

\section{Mass Spectrometry}

Two degrees of freedom were avallable for spectrometric measurements. The probe could be positioned through the use of stepper motors to view selected radial locations along the thruster diameter from various dispersion angles in the range of $\pm 15^{\circ}$ from horizontal. Two modes of operation of the spectrometer were also available; static mode and dynamic mode. 
In the static mode, the probe was positioned at the centerine of the thruster. This position was found by adjusting the radial location of the probe about a preset centerline unt11 a maximum current was measured. The probe was then articulated through a range of dispersion angles until again a position of maximum signal strength was identified, parallel to the thruster beam. At this centerline position, a trace of probe current collected versus separator plate voltage (velocity selector) was made. The separator plate voltages associated with the singly-and doubly-charged fon current peaks were recorded and verified using the expression:

$$
V_{S}=\left(2 e V_{B} / M\right)^{1 / 2} B d
$$

where $V_{B}$ is the thruster beam voltage, $M$ is propellant specie mass in $\mathrm{Kg}$, B is the mass separator magnetic fields $(=0.4 \mathrm{~T})$, and $\mathrm{d}$ is the mass separator plate spacing $\left(=4 \times 10^{-3} \mathrm{~m}\right)$. Typical probe currents were on the order of $10^{-10}$ to $10^{-72} \mathrm{~A}$.

In the dynamic mode, the separator plate voltage was tuned to the current peaks of each charge specie. A trace was then made of this peak collector current as a function of probe position from thruster centerine to a location out of the beam at fixed angle. This generated a beam profile of each specie.

Because extensive mass spectrometry was conducted for both the ring-cusp and $\mathrm{J}$-series thruster, the discharge chamber performance presented herein was also corrected to account for doubly-charged ion current. In all cases, triply charged xenon ions accounted for less than one percent of the total ion current, which is comprised primarily of currents due to singly $\left(I^{+}\right)$or doubly charged $\left(I^{++}\right)$lons. Using the worst case centerline $I^{++} / I^{+}$values, an ion mass flowrate correction factor $(B)$ was calculated to adjust the discharge chamber propellant efficiency. The factor $\beta^{\prime}$ is defined to be the ratio of the actual ion mass flow rate in equivalent amperes to the measured beam current. A thrust correction factor $(\alpha)$, and a 0.98 thrust reduction factor due to beam divergence, were also used to adjust the overall thruster efficiency and specific impulse. The factor $\alpha$ is defined to be the ratio of actual to ideal thrust as a consequence of multiply charged ions. The ion beam production cost, however, is simply defined as the ratio of discharge power to measured ion beam current.

\section{RESULTS AND DISCUSSION}

The ring-cusp thruster technology issues are presented in separate discussions of discharge ignition, discharge chamber performance, overall thruster efficiency, and thruster lifetime. In each section, comparisons are made to the J-series thruster.

\section{Discharge Ignition}

Discharge ignition in the ring-cusp thrusters was accomplished by applying a $3-k V, 3-\mu s$ pulse between a tungsten wire electrode and the cathode tip, or by applying $1200 \mathrm{~V}$ open circuit voltage to an external keeper electrode. The discharge could be reliably initiated without preheating the cathode insert, at standard operating cathode flow rates of 0.13 to $0.47 \mathrm{eq}$. A. With the wire electrode. After the gas breakdown, the discharge immediately coupled between 
cathode and anode, and was sustained without requirement of a cathode keeper. It is the experience of this author, and was documented in reference 10, that ignition without cathode insert preheating in the J-series thruster requires approximately two orders of magnitude higher cathode flow rate for equivalent cathode geometries. However, a standard start-up procedure was not addressed in this investigation.

\section{Discharge Chamber Performance}

Impact of hollow cathode operation. - The impact of hollow cathode operation on thruster performance was observed in this investigation. This performance impact manifested itself in two ways; (1) the impact of cathode flow rate adjustment on operating discharge voltage, and subsequently, the ion beam production cost, and (2) temporal changes in the baseline ion beam production cost as a consequence of changes in the insert and/or insert work function. These phenomena were observed in both the ring-cusp and J-series thrusters with xenon. However, the J-series thruster operating voltage is typically less sensitive to cathode flow rate adjustment than that presented here for the ring-cusp thruster. Testing was conducted to quantify these phenomena.

Figure 3 illustrates a typical discharge voltage dependence on cathode flow rate for the ring-cusp discharge. Best performance of the thruster configuration is normally achieved by operating near the knee of the discharge voltage-/cathode flow rate curve to achieve a minimum ion beam production cost. This is done by simultaneously observing the increase in beam current and operating discharge voltage assoclated with the cathode flow rate reduction. For cathode flow rates below the knee, the thruster enters a mode where the operating discharge voltage rapidly increases to a value in excess of $50 \mathrm{~V}$. For cathode flow rates much greater than the flow at the knee, the thruster typically enters a mode of operation where the propellant efficiency drops as a consequence of too much propellant for the given discharge power. As indicated, for increasing levels of discharge power (discharge current) the location of the knee shifts rightward, thus requiring higher cathode flow rates to maintain moderate values of discharge voltage if the flow rate directly into the chamber is fixed. The desired discharge voltage is $<32 \mathrm{~V}$ for xenon to reduce the sputter-yield of discharge plasma ions striking the cathode potential molybdenum screen grid. Figure 4 illustrates the sensitivity of the thrust and specific impulse to cathode flow rate adjustment. As indicated, the lowest value of. cathode flow rate provides modest discharge voltages, higher discharge powers, and consequently, higher levels of thrust and specific impulse. These parameters were typically insensitive to main flow rate adjust:ment at fixed discharge power. For near-earth, high power applications the thrusters would not be throttled, eliminating the need for active cathode flow adjus tment.

During evaluation of configuration number $3 E$, a change was made in the cathode insert, which resulted in a change in baseline ion beam production cost of approximately $20 \mathrm{~W} / \mathrm{A}$. As indicated in figure 5 , test 1 was conducted with a cathode insert with leads spot-welded to the cathode body, while test 2 was conducted with a leadless insert crimped into the cathode body. From a .V-I characteristic of these tests, it is apparent that the increase in production cost is associated with an increase in discharge current to maintain the same beam current. This shift in discharge current was probably due to a 
change in emission surface caused by the two techniques of establishing thermal and electrical contact between insert and cathode body or simply a contact resistance effect: Careful attention should be made to electrically connect the cathode insert to the nonductile refractory metal cathode tube in order to preserve reproducible, efficient operating conditions.

Performance/throttling comparison. - Figure 6 presents performance curves for six of the twelve configurations investigated, along with total propellant flow rates. Table IV presents detalled discharge chamber performance for these configurations at near -90 percent propellant efficiency. The highest performance levels (lowest ion beam production cost) achleved in this investigation were with configuration number 2 . The performance levels attained in reference 13, shown in table $V$, were not successfully duplicated in this investigation. The difference in baseline production cost documented in Table $V$ and those documented here were principally due to higher measured beam current. Based on experiments conducted at a variety of neutralizer cathode operating conditions, it was determined that these beam current levels were due to contributions from electron current penetrating the $0.19-\mathrm{cm}$ hole diameter50 percent open area fraction discharge chamber ground screen used to shield the thruster high potential surfaces. This resulted in measured ion beam production cost levels lower than the actual values. Subsequent experiments indicated that $0.05-\mathrm{cm}$ hole diameter -20 percent open area fraction ground screen used in this investigation would shield the thruster high potential surfaces, eliminating electron backstreaming from the neutralizer cathode.

Figure 7 presents the performance curves for configuration number 2 for increasing propellant flow rates. These indicate a reduction in the baseline production cost with increasing flow rate, as predicted by thruster performance modeling (ref. 22). Uncorrected propellant efficlencies at times were above 100 percent, indicating that the discharge chamber length was too long for operation with xenon due to substantial multiple-ionization of the propellant gas. The discharge chamber length was optimized for argon (ref. 26), which has higher ionization energies than xenon.

A direct comparison of thruster performance from configuration-toconfiguration is difficult using only the performance curves of figure 6 . Each configuration was optimized at its specific main and cathode flows and discharge power which would provide stable operation at low values of lon beam production cost and high propellant efficiencies. The performance curves do not indicate which configuration would operate best in a throttling mode. Throttling curves were generated to define a minimum ion beam production cost for a configuration at several total flow rates at a specified propellant efficiency. Figure 8 presents throttling curves for the seven configurations of table IV at near 90 percent propellant efficiency and comparison is made at comparable total propellant flow rates. Several of the thruster configurations were not plotted because stable operation (i.e., beam extraction) was achieved at only one value of beam current.

As indicated in figure 8 , thruster configuration number 2 achleved the best performance over the 2 to 1 throttling range investigated. From the throttling curves and table II, it is observed that small changes in the magnetic configuration result in large changes in the baseline ion production cost. For configurations numbers 1, 1A, and 2, which have nearly identical magnetic geometries, the baseline ion production costs are comparable at 
equivalent total propellant flow rates. An increase in the baseline production cost was observed at high total xenon flow rates for configurations with higher magnetic field strengths at the back of the discharge chamber or cathode orifice, or for reduced downstream side wall field strengths, than those measured in configuration number 2 . These include magnetic configuration numbers $3 C$ and 4B. For increased magnet field strengths along the side wall anode above the $0.27 \mathrm{~T}$ level in configuration number 2 , severe discharge instabllities 1 imited the range of stable operation (configuration numbers $4,4 A, 4 B ; 5$ ). Analysis of the discharge $V-I$ characteristics of the thruster configurations operated at near 2.9 A total propellant flow rate (fig. 8 ) indicate that the reduced ion beam production costs achieved with configuration number 2 were primarily due to lower discharge voltages at comparable discharge and beam currents.

A discharge chamber performance comparison of ring-cusp configuration number 2 to the divergent-field J-8 thruster is presented in the throtting curves of figure 9. Performance data for these thrusters at near 90 percent corrected propellant efficlency is presented in table VI. The data for the J-8 thruster represents the lowest ion beam production cost attained at high propellant efficiencies with conventional divergent field thrusters and is comparable to data documented in reference 10. As indicated, the ring-cusp thruster performs better over the entire range of throttling conditions investigated. The indicated discharge voltages represent the values necessary to obtain the minimum production cost at the corresponding total flow rate for propellant efficiencies in excess of 90 percent. The minimum J-8 thruster discharge voltage was approximately $32 \mathrm{~V}$, whereas the ring-cusp thruster could be operated at $28 \mathrm{~V}$ discharge by increasing the cathode flow rate and st 111 maintain discharge losses below those of the J-8 thruster at comparable total flow rates.

A variety of modifications to the J-8 thruster discharge chamber were evaluated in an attempt to improve the baseline ion production cost, and reduce the operating discharge voltage. Discharge chamber performance for a modified J-8 thruster (baffle removed) indicated operating discharge voltages could be reduced below $30 \mathrm{~V}$, at the expense of a substantial performance degradation. As indicated in figure 9, the baseline production cost was in excess of 200 W/A for beam currents below $5.4 \mathrm{~A}$, and leveled off at $160 \mathrm{~W} / \mathrm{A}$ for beam currents in excess of $7.8 \mathrm{~A}$. Stable operation with beam extraction could not be maintained without a cathode keeper discharge. Attempts at reducing the baseline ion beam production. cost below the $160 \mathrm{~W} / \mathrm{A}$ level demonstrated for the standard J-8 geometry were unsuccessful.

To summarize, the baseline ion production cost of the ring-cusp and J-8 thrusters decreased with total xenon flow rate at fixed propeliant efficiency. The ring-cusp thruster demonstrated superior performance over the 2 to 1 range of flow rate. Further improvements in the baseline production cost of the ring-cusp thruster would be anticipated with a reduced discharge chamber length. The throttling characteristics, however, were sensitive to small changes in the magnetic field configuration of the discharge chamber. The ring-cusp thruster could be operated at reduced discharge voltages by cathode flow rate adjustment and still maintain discharge losses below those demonstrated for the J-8 thruster. Attempts at reducing the operating voltage of the J-8 thruster below $32 \mathrm{~V}$ lead to severe degradations in discharge chamber performance. Modifications to the J-8 thruster discharge chamber did not yield reductions below $160 \mathrm{~W} / \mathrm{A}$. The lower discharge losses demonstrated with the 
ring-cusp thruster would result in reduced thruster thermal loading and reduced cathode self-heating. Based on the thruster performance demonstrated here, incorporation of the ring-cusp discharge chamber technology into the $50-\mathrm{cm}$ thruster array proposed for the SP-100 reference mission (ref. 7) would reduce the total dissipated power requirements by $6 \mathrm{~kW}$, and the cathode emission current levels by $18 \mathrm{~A}$ (25 percent) per-thruster.

Distribution of currents to anodes. - Electron currents to the magnet rings were measured for six of the configurations investigated. This effort was directed toward associating the distribution of discharge current to the ion beam production cost. The current to each of the magnet rings was measured by positioning a steel ring above the magnets. The ring was electrically isolated from the magnets with a $0.006 \mathrm{~cm}$-thick sheet of Kapton $\mathrm{film}$. The rings were then connected through a current sensor, and tied to anode potential.

For configurations numbers $1 A, 2$, and $3 C$, only the discharge current to magnet ring number 4 was measured with a current sensor. As shown in table VII, the electron currents measured at ring number 4 were only on the order of 0.4 to 0.6 percent of the total discharge current. These values were comparable to those measured by Sovey with configuration number 1 . Further, when biasing ring number 4 to cathode potential, no appreciable ion currents were measured.

Table VII also lists the electron current values measured for configurations numbers $3 E, 4 B$, and 5 . For these, four currents sensor were used; one each for magnet rings numbers 1,2 , and 6 , and one for rings numbers 3,4 , and 5, which were electrically connected together. As indicated, the currents measured to magnet rings numbers 1 and 2 constituted 70 to 90 percent of the total discharge current collected. This is consistent with Sovey's observation of configuration number 1 that nearly all of the electron current was collected by the downstream magnet rings. No appreciable electron currents $(<0.3$ percent of $J_{0}$ ) were measured to rings numbers 3 to 5 . The electron currents to pole piece ring number 6 were in the range of 6 to 17 percent of the total discharge current. The difference between the discharge current and the total current measured to the six magnet rings is presumed to be electrons collected at the anode she 11 between the magnet rings.

As seen in figures $1(a)$ and 2 , magnet ring number 2 is the opposite polarity of the cathode magnet. These two couple magnetically, effectively defining an upstream boundary to electron and ion losses. Because no significant electron or lon currents were measured upstream of ring number 2, this suggested that ring numbers 3 to 5 were not contributing electricaliy to the performance of the thruster. Consequently, studies using configuration number $3 E$ were undertaken to investigate the impact of electrically isolating individual magnet rings, and noting the impact on performance, if any.

As indicated in table VII and figure 10, as the total discharge current is increased, the individual currents to each of the magnet rings increases proportionately. However, there does appear to be a current redistribution between magnet rings numbers 2 and 6 . Approximately $1 \mathrm{~A}$ of electron current is redistributed between the two rings of same polarity at high discharge power. This shifting of electron currents did not have an impact on the extracted ion fraction because no fluctuations in the beam current were observed. 
Table VIII lists the distribution of electron currents and performance levels for three alterations to configuration number $3 E$ : magnet ring number 2 electrically isolated (1.e., floating potential); magnet rings numbers 3,4 , and 5 electrically isolated; and magnet rings numbers 3, 4, 5, and 6 electrically isolated. The performance curves for thse alterations are presented in Figure 11. As indicated when magnet ring number 2 was electrically isolated, the electron current originally collected there redistributed itself to the other cusps. This alteration resulted in an increase in ion beam production cost of $10 \mathrm{~W} / \mathrm{A}$ due to an increase in discharge voltage. With ring number 2 isolated, the thruster suffered severe discharge instablitities. A discharge could not be maintained for $J_{0}>12.8 \mathrm{~A}$. When magnet rings numbers 3,4 , and 5 were isolated, no significant change in production cost or discharge voltage occurred. There were also no discharge instabilities. This indicated that magnet rings numbers 3,4 , and 5 may not be critical to thruster performance, and could be eliminated electrically from the design. Finaliy, when magnet ring number 6 was isolated along with rings numbers 3 to 5 , an increase of 5 to $10 \mathrm{~W} / \mathrm{A}$ occurred. This increase is associated with a decrease in the measured beam current at comparable discharge power. This suggests that the presence of pole piece magnet ring number 6 increases the extracted ion fraction by enhancing the forward ion flux to the grid system.

As indicated in table VII, most of the discharge current for the high field strength configuration number 5 was collected at ring number 2 . This may have contributed to the poor performance and instability of the design by loss of energetic electrons directly to the anode without lonizing neutral propellant, and by reducing the effective anode area.

To summarize, electron currents to the magnet rings were measured to attempt to associate the distribution of discharge current to the ion beam production cost. It was found that the performance was dependent on the distribution of currents to the two furthest downstream magnet rings. Seventy to ninety percent of the total discharge current was collected at these rings for those thrusters which operated stably at low values of production cost.

Thermal data. - Measurements of the magnet surface temperatures as a function of discharge power were made for a simplified ring-cusp thruster configuration, similar in magnetic circuit to the thruster independently developed by Beattie and others (ref. 16). Data without water cooling of the anode shell indicated magnet temperatures from 160 to $210{ }^{\circ} \mathrm{C}$ for discharge power ranging from 330 to $400 \mathrm{~W}$, which are consistent with data reported by James (ref. 17). Based on the performance documented for configuration number 2, and therma 1 data presented in references 14 and 17 , steady state magnet temperatures would not be expected to exceed $250{ }^{\circ} \mathrm{C}$ for thruster power levels up to $10 \mathrm{~kW}$. This is below the temperature which would result in irreversible loss in magnet properties.

\section{Overall Thruster Efficiency}

The overall thruster performance of several of the ring-cusp thruster configurations with xenon propellant is presented in table IX. The correction factors for doubly-charged ions and beam divergence were made to the data as indicated previously. Total propellant flow rates and correction for gas ingestion include a neutralizer flow rate of 0.1 eq. ampere. Total input 
power also includes a value of $40 \mathrm{~W}$ for the neutralizer. Thruster performance was demonstrated for thrust levels of $0.28 \mathrm{~N}$ at input power levels in excess of $8 \mathrm{kH}$.

Figure 12 shows the demonstrated thruster efficiencies as a function of specific impulse for several of the ring-cusp thruster configurations. The range of specific impulse over which each configuration was operated was due to increasing propellant efficiencies from 80 to 90 percent at a fixed beam voltage. The difference in demonstrated specific impulse for the configurations at fixed propellant efficiency is a consequence of operating at different beam voltages. As indicated, an overall efficiency of 70 percent was attained at about $3500 \mathrm{sec}$ specific impulse, which correspond to power-tothrust levels of 25 to $27 \mathrm{w} / \mathrm{mN}$. Figure 13 shows the demonstrated efficiency/ specific impulse curves for the ring-cusp thruster configuration number 2 , and the J-8 and modified J-8 thruster. As indicated, the ring-cusp thruster operates at higher thruster efficiencies than the J-8 and modified J-8 thrusters at a given value of specific impulse. This is a consequence of the ringcusp discharge chamber operating at lower values of ion beam production cost. Projected performance for the thrusters is also presented. The projected performance was generated using a fixed total voltage and varying the beam voltage across the range of specific impulse, and assuming the beam current density expression of reference 26 at a total propellant efficiency of 90 percent. The discrepancy in demonstrated to projected performance is because the projected data assumes zero thrust loss due to multiply charged ions, and a fixed value of 0.98 for the beam divergence over the range of net-to-total voltage.

The improved thruster efficiency with the ring-cusp discharge impacts both the thruster system as well as mission performance. With the lower levels of production cost associated with the ring-cusp discharge, a significant reduction in thruster thermal loads as well as reduced cathode self-heating is achieved for high power operating levels, as indicated earlier. The increased thrust-to-power ratio of the ring-cusp thruster would also provide for reduced trip time duration for near-earth orbit transfers.

\section{Thruster Lifetime}

The production of doubly-charged ions in the discharge of a thruster is not desirable because they cause excessive sputter-erosion of thruster components. Investigations by Mantenieks and Rawlin (refs. 19 to 21) have concluded that this constitutes one of the major life-limiting phenomena to extended thruster operation. For this reason, there have been numerous investigations (refs. 22, 27 to 36), undertaken to predict the doubly-charged ion content, given plasma properties or design and operating parameters of the thruster. However, there had been no extensive beam mass spectrometry conducted for the ring-cusp or J-series thrusters with xenon propellant.

Mass spectrometry was conducted with xenon propellant for five of the ring-cusp thruster configurations in this study, including numbers $1,1 \mathrm{~A}, 2$, $3 C$ and $3 E$ (table $X$ ), as well as the J-8 thruster. The probe data used in the analysis was the ratio of the doubly-to-singly charged ion current peak heights as measured at thruster centeriine. Triply charged species contributed less than 1 percent to the total beam current. Analysis of the beam data off-axis as well as at various dispersion angles from horizontal indicated that the ratio of peak heights at centerline would provide a conservative estimate of 
total ion current ratio in the beam. The centerline ratio should provide a relative measure of the ion optics grid erosion at its maximum.

Figures 14 and 15 show the centerline values of double-to-single fon current ratios as a function of propeliant efficiency for the indicated thruster configurations and total flow rates. The curves were generated by measuring the species current ratios along the thruster performance curve, at each point of increasing discharge and beam current. Figure 14 indicates a relative insensitivity of the species current ratio to ring-cusp magnetic configuration. Figure 15 indicates a sensitivity of the species current ratio to beam current. This apparent sensitivity to increasing total flow may be a consequence of reduced electron temperatures resulting in a lower rate factor for single ionization of ground state atoms, or may simply be attributed to a more peaked spatial profile. Table $X$ presents a summary of the species current ratios measured at near 90 percent propellant efficiency for the ring-cusp thruster.

Figure 16 shows the species current ratios as a function of propellant efficiency for the ring-cusp and J-series thrusters at $2.0 \mathrm{~A}$ total flow rate of xenon propellant. Also presented is data from the J-series thruster with mercury (ref:. 10 - with corrected efficiencies), as well as the minimum double ionization operating curve for a 900-series divergent-field thruster with mercury propellant from reference 36 . As indicated, both the ring-cusp and J-series thrusters centerline species current ratio with xenon are typically less than half the value of the integrated species current ratio for a 900series thruster with mercury, whereas the reduction from J-series mercury data is only on the order of 30 percent.

As Figure 16 shows, the double-to-single ion current ratio for the $\mathrm{J}$-series thruster with xenon is approximately 0.09 at 90 percent propellant efficlency, whereas the ratio is approximately 0.06 for the ring-cusp thruster. This indicates that the ring-cusp thruster would exhibit less centerline screen-grid erosion than the J-series thruster because of lower levels of doubly charged ions on centerline. As discussed earlier, the minimum operating discharge voltage for the J-8 thruster at discharge propellant efficiencies above 90 percent was $32 \mathrm{~V}$, whereas the ring-cusp thruster configuration number 2 could be operated at $28 \mathrm{~V}$ discharge voltage and still maintain discharge losses below those of the J-8 thruster. Using sputter ylelds for $\mathrm{Hg}$ ions on molybdenum from Askerov and Sena (ref. 37), and assuming similar trends for Xe ions differing only by a constant (ref. 10), the average screen grid erosion rate for the J-series thruster operating with xenon is calculated to be 1.97 times that of the ring-cusp thruster with xenon propellant. This estimate is conservative because it assumes comparable centerline ion current ratios of 0.09 at 90 percent propellant efficiency for both thrusters. Based on the lower centerline values of doubly charged ions and the lower operating discharge voltage, the ring-cusp thruster would be expected to have a screen grid iffetime a factor of approximately two higher than the divergent-field J-series thruster. 


\section{CONCLUDING REMARKS}

The performance characteristics and operating envelope of several $30-\mathrm{cm}$ ring-cusp thrusters with xenon propellant were investigated. The scope of the investigation included: (1) assessing the performance characteristics and operating envelope of several ring-cusp thrusters; (2) conducting beam mass spectrometry of the ring-cusp and J-series thrusters with xenon propellant; and (3) to provide a significant data base to assist in comparing the operating characteristics of the ring-cusp and J-series divergent-field thrusters with xenon propellant.

The baseline ion production cost of the ring-cusp and J-8 thrusters decreased with total xenon flow rate at fixed propellant efficiency. The ringcusp thruster demonstrated superior performance over the 2:1 range of flow rate with a minimum production cost of 120 W/A at 90 percent propellant efficiency. Further improvements in the baseline production cost of the ring-cusp thruster would be anticipated with a reduced discharge chamber length. The throttling characteristics, however, were sensitive to small changes in the magnetic field configuration of the discharge chamber. The ring-cusp thruster could be operated at reduced discharge voltages by cathode flow rate adjustment and still maintain discharge losses below those demonstrated for the J-8 thruster. Attempts at reducing the operating voltage of the J-8 thruster below $32 \checkmark$ lead to severe degradations in discharge chamber performance. Modifications to the J-8 thruster discharge chamber did not yield reductions below $160 \mathrm{~W} / \mathrm{A}$. The lower discharge losses demonstrated with the ring-cusp thruster would result in reduced thruster thermal loading and cathode self-heating. Based on the thruster performance demonstrated here, incorporation of the ringcusp discharge chamber technology into the $50-\mathrm{cm}$ thruster array proposed for the SP-100 reference mission would reduce the total dissipated power requirements by $6 \mathrm{~kW}$ and the cathode emission current levels by $18 \mathrm{~A}$ (25 percent) per thruster.

Electron currents to the magnet rings of ring-cusp thrusters were measured to attempt to associate the distribution of discharge current to the ion beam production cost. It was found that the performance was dependent on the distribution of currents to the two furthest downstream magnet rings. Seventy to ninety percent of the total discharge current was collected at these rings for those thrusters which operated stably at low values of production cost.

The overall thruster performance of the ring-cusp thrusters was superior to that demonstrated with the J-8 and modified J-8 thrusters, including higher thrust-to-power ratios over the range of specific impulse. This is a consequence of the lower levels of production cost associated with the ring-cusp discharge. Typical thruster efficiencies of 70 percent were attained at about $3500 \mathrm{sec}$ specific impulse with the ring-cusp thruster, which correspond to power-to-thrust levels of 25 to $27 \mathrm{w} / \mathrm{mN}$.

Mass spectrometry of the ion beam of both the ring-cusp and J-series thrusters indicate that the centerline species current ratio with xenon is approximately 30 percent lower than that measured with the J-series operating on mercury propellant. The species current ratio for the ring-cusp thruster was lower than that of the $\mathrm{J}$-series thruster at fixed propellant efficiencies. Based on the lower centerline values of doubly charged ions and the lower operating discharge voltage, the ring-cusp thruster would be expected to have 
a screen grid lifetime a factor of 2 higher than the divergent-field J-series thruster.

\section{REFERENCES}

1. Wilbur, P.J., "Electrostatic Thruster Capabilities for Orbit-Raising and Maneuvering Missions," Orbit Raising and Maneuvering Propulsion: Research Status and Needs, edited by L.H. Caveny, Progress in Astronautics and Aeronautics, Vol. 89, AIAA, New York, 1984, pp. 327-344.

2. Kaufman, H.R. and Robinson, R.S., "Electric Thruster Performance for Orbit-Raising and Maneuvering, "Orbit Raising and Maneuvering Propulsion: Research Status and Needs, edited by L.H. Caveny, Progress in Astronautics and Aeronautics, Vol. 89, AIAA, New York, 1984, pp. 303-326.

3. Rawlin, V.K. and Patterson, M.J., "Performance of 30-cm Xenon Ion Thrusters," AIAA Paper 85-2009, Oct. 1985.

4. "Initial Technical, Environmental, and Economic Evaluation of Space Solar Power Concepts. Vol. 2: Detailed Report," NASA TM X-74310, 1976.

5. Byers, D.C., Terdan, F.F., and Myers, I.T., "Primary Electric Propulsion for Future Space Missions," AIAA Paper 79-0881, May 1979.

6. Byers, D.C., "Characteristics of Primary Electric Propulsion Systems," AIAA Paper 79-2041, Oct. 1979.

7. Berkopec, F.D., NASA Lewis Research Center, "Ion Propulsion for SP-100," Unpubilished, Mar. 1986.

8. Patterson, M.J., NASA Lewis Research Center, "Ion Propulsion System for Manned-Mars Mission," (to be presented at the AIAA Electric Propulsion Conference, Apr. 1987).

9. Byers, D.C., and Rawlin, V.K., "Critical Elements of Electron-Bombardment Propulsion for Large Space Systems," Journal of Spacecraft and Rockets, Vo1. 14, No. 11, Nov. 1977, pp. 648-654.

10. Rawlin, V.K., "Operation of the J-Series Thruster Using Inert Gases," AIAA Paper 82-1929, Nov. 1982.

11. Byers, D.C., and Rawlin, V.K., "Electron Bombardment Propulsion System Characteristics for Large Space Systems," AIAA Paper 76-1039, Nov. 1976.

12. Martin, A.R., and Bond, A., "A Review and Assessment of the Performance of Advanced Ion Thrusters," IAF Paper 85-202, Oct. 1985.

13. Sovey, J.S., "Improved Ion Containment Using a Ring-Cusp Ion Thruster," Journal of Spacecraft and Rockets, Vo1. 21, No. 5, Sept.-Oct. 1984, pp. 488-495.

14. Beattie, J.R., and Kami, S., "Advanced-Technology 30-cm Diameter Mercury Ion Thruster," AIAA Paper 82-1910, Nov. 1982. 
15. Poesche1, R.L., "Development of Advanced Inert-Gas Ion Thrusters," Hughes Research Labs, Malibu, CA, NASA CR-168206, 1983.

16. Beattie, J.R., Matossian, J.N., Poeschel, R.L., Rogers, W.P., and Martine 111, R., "Xenon Ion Propulsion Subsystem," AIAA Paper 85-2012, Sept. 1985.

17. James, E.L., "Advanced Inert Gas Ion Thrusters," Loral Electro-Optical Systems, Pasadena, CA, FR-R83-05-39, July 1984. (NASA CR-168192)

18. Vahrenkamp, R.P., "Measurement of Double Charged Ions in the Beam of a 30-cm Mercury Bombardment Thruster," AIAA Paper 73-1057, Oct. 1973.

19. Mantenieks, M.A., and Rawlin, V.K., "Studies of Internal Sputtering in a 30-cm Ion Thruster," AIAA Paper 75-400, Mar. 1975.

20. Mantenieks, M.A., and Rawlin, V.K., "Sputtering Phenomena of Discharge Chamber Components in a 30-cm Diameter HG Ion Thruster," AIAA Paper 76-988, Nov. 1976.

21. Mantenieks, M.A., and Rawlin, V.K., "Sputtering in Mercury Ion Thrusters," AIAA Paper 79-2061, Oct. 1979.

22. Brophy, K.R., "Ion Thruster Performance Mode1," Colorado State University, Fort Collins, CO, NASA CR-174810, 1984.

23. Schnelker, D.E., Collet, C.R., Kami, S., and Poesche1, R.L., "Characteristics of the NASA/Hughes J-Series 30-cm Engineering Model Thruster," AIAA Paper 79-2077, Oct. 1979.

24. Gilbert, J., and Guttman, C.H., "Evolution of the SEP Stage/SEPS/Concept," AIAA Paper 73-1122, Nov. 1973.

25. Maloy, J. (Project Manager), Acceptance Test Document for 30-cm Thruster 38, Contract NAS3-21747, May 1981.

26. Sovey, J.S., "A 30-cm Diameter Argon Ion Source," AIAA Paper 76-1017, Nov. 1976.

27. Peters, R.R., "Double Ion Production in Mercury Thrusters," Colorado State University, Fort Collins, CO, NASA CR-135019, 1976.

28. Peters, R.R., Wilbur, P.J., and Vahrenkamp, R.P., "A Doubly Charged Ion Model for Ion Thrusters," AIAA Paper 76-1010, Nov. 1976.

29. Beattie, J.R., "Cusped Magnetic Field Mercury Ion Thruster," Colorado State University, Fort Collins, CO, NASA CR-135047, 1976.

30. Wilbur, P.J., "8-cm Thruster Tests," Mercury Ion Thruster Research, Colorado State University, Fort Col11ns, CO, NASA CR-135317, 1977, pp. 96-104.

31. Kaufman, H.R., "Experimental Investigations of Argon and Xenon Ion Sources," Colorado State University, Fort Collins, CO, NASA CR-134845, 1975. 
32. Wilbur, P.J., "Argon-Xenon Discharge Chamber Model for the Production of Doubly Charged Ions Theory, "Inert Gas Thrusters, H.R. Kaufman, Colorado State University, Fort Colitins, CO, NASA CR-135226, 1977, Pp. 46-64

33. Kaufman, H.R., and Robinson, R.S., "Doubly Charged Ion Production," Inert Gas Thrusters, Colorado State University, Fort Collins, CO, NASA CR-159813, 1979, pp. 24-42.

34. Kaufman, H.R., and Robinson, R.S., "Doubly Ionized Propellant," Inert Gas Thrusters, Colorado State University, Fort Collins, CO, NASA CR-165332, 1980, pp. 18-21

35. Beattie, J.R., "Single and Double Ion Beam Current Determination," 15-cm Mercury Ion Thruster Research - 1975, P.J. Wilbur, Colorado State University, Fort Coll1ins, CO, NASA CR-134905, 1975, Pp. 100-106.

36. Vahrenkamp, R.P., "An Experimental Investigation of Multiple Ion Processes in Mercury Bombardment Thrusters," AIAA Paper 75-397, March 1975.

37. Askerov, S. G., and Sena, L. A., "Cathode Sputtering of Metals by Slow Mercury Ions," Soviet Physics-Solid State, Vol. 11, No. 6, Pp. 1288-1293, December 1969. 
TABLE I. - RING-CUSP PARAMETERS

\begin{tabular}{|c|c|c|c|c|c|c|c|c|c|c|c|c|c|c|c|c|c|c|c|}
\hline \multirow[t]{2}{*}{$\begin{array}{c}\text { Thruster } \\
\text { conf iguration }\end{array}$} & \multirow{3}{*}{$\begin{array}{c}\text { Ion } \\
\begin{array}{c}\text { extraction } \\
\text { dianeter, } \\
\mathrm{cm}\end{array} \\
28.3\end{array}$} & \multirow{3}{*}{$\begin{array}{c}\text { Cylindrical } \\
\text { shell } \\
\text { length, } \\
\mathrm{cm}\end{array}$} & \multirow{3}{*}{\begin{tabular}{|c|}
$\begin{array}{c}\text { cylindrical } \\
\text { shell } \\
\text { diameter, } \\
\text { cm }\end{array}$ \\
34.3 \\
\end{tabular}} & \multirow{3}{*}{\begin{tabular}{|c|c|}
$\begin{array}{c}\text { Number of } \\
\text { magnet rings } \\
\text { on cylindrical } \\
\text { wall icl }\end{array}$ \\
3 \\
\end{tabular}} & \multicolumn{3}{|c|}{$\begin{array}{l}\text { Magnet ring } \\
\text { axial location } \\
\mathrm{cm}\end{array}$} & \multicolumn{3}{|c|}{$\begin{array}{l}\text { Magnet field } \\
\text { strength, } \\
T\end{array}$} & \multicolumn{2}{|c|}{$\begin{array}{c}\text { Magnet ring } \\
\text { radial } \\
\text { location } \\
\text { from thruster } \\
\text { centerline } \\
\text { on backplate, } \\
\text { cm }\end{array}$} & \multicolumn{2}{|c|}{$\begin{array}{c}\text { Magnet } \\
\text { field } \\
\text { strength, } \\
T\end{array}$} & \multirow{2}{*}{$\begin{array}{c}\text { Cathode magnet } \\
\text { strength } \\
\text { and polarity } \\
\text { at cathode tip. } \\
T\end{array}$} & \multirow{2}{*}{\begin{tabular}{|c|}
$\begin{array}{c}\text { Cathode } \\
\text { length, } \\
\mathrm{cm}\end{array}$ \\
\end{tabular}} & \multirow{2}{*}{$\begin{array}{c}\text { Orifice } \\
\text { size, } \\
\mathrm{cm}\end{array}$} & \multirow{2}{*}{\begin{tabular}{|c}
$\begin{array}{c}\text { Magnet ring } \\
\text { inner diameter } \\
\text { on downstream } \\
\text { pole piece, } \\
\mathrm{cm}\end{array}$ \\
6
\end{tabular}} & \multirow{2}{*}{\begin{tabular}{|c}
$\begin{array}{c}\text { Magnet field } \\
\text { strength, } \\
T\end{array}$ \\
6
\end{tabular}} \\
\hline & & & & & 1 & 2 & 3 & 1 & 2 & 3 & 4 & 5 & 4 & 5 & & & & & \\
\hline $\begin{array}{l}1 \\
1 \mathrm{~A} \\
2 \\
3 \\
3 \mathrm{~A} \\
3 \mathrm{~B} \\
3 \mathrm{C} \\
3 \mathrm{D} \\
3 \mathrm{E} \\
4 \\
4 \mathrm{~A} \\
4 \mathrm{~B} \\
5\end{array}$ & & & & & 3.8 & 11.4 & 22.9 & $\begin{array}{l}1 \\
.13 \\
.27 \\
.27 \\
.27 \\
.32\end{array}$ & $\begin{array}{l}1 \\
.13 \\
.27 \\
.27 \\
.27 \\
.32\end{array}$ & $\begin{array}{l}\downarrow \\
.13 \\
.32 \\
.32 \\
.30 \\
.32\end{array}$ & 6.8 & 15.2 & $\begin{array}{l}1 \\
.27 \\
.32 \\
.32 \\
.27 \\
.27\end{array}$ & $\begin{array}{l}1 \\
.27 \\
.32 \\
.32 \\
.27 \\
.27\end{array}$ & $\begin{array}{l}0.025 \mathrm{~N} \\
.025 \mathrm{~N} \\
.0255 \mathrm{~N} \\
.026 \mathrm{~N} \\
.019 \mathrm{~N} \\
.019 \mathrm{~N} \\
.0285 \mathrm{~N} \\
.031 \mathrm{~N} \\
.0285 \mathrm{~N} \\
.026 \mathrm{~N} \\
.026 \mathrm{~N} \\
.0285 \mathrm{~N} \\
.030 \mathrm{~N}\end{array}$ & $\begin{array}{l}6.3 \\
6.3 \\
6.3 \\
7.6 \\
7.6 \\
6.3\end{array}$ & $\begin{array}{l}0.051 \\
.051 \\
.160 \\
.006 \\
.130 \\
.0511 \\
.130 \\
.100 \\
.051 \\
.130 \\
.76 \\
.76 \\
.130 \\
.130\end{array}$ & $\begin{array}{l}28.3 \\
28.3 \\
28.3 \\
---. \\
28.3\end{array}$ & $\begin{array}{l}0.27 \\
0.27 \\
0.27 \\
-0.27 \\
0.27\end{array}$ \\
\hline
\end{tabular}

Magnets are 35 percent samarium -65 percent cobalt, $1.3 \times 1.9 \times 0.5 \mathrm{~cm}$. 
TABLE II. - RING-CUSP CONFIGURATION CHANGES

\begin{tabular}{|c|c|c|c|c|c|c|c|}
\hline \multirow{2}{*}{$\begin{array}{l}\text { Thruster } \\
\text { configuration } \\
\text { - }\end{array}$} & \multicolumn{7}{|c|}{ Modifications to field strength at magnet rings } \\
\hline & 1 & 2 & 3 & 4 & 5 & 6 & Cathode orifice \\
\hline $\begin{array}{c}\text { (Baseline } \\
\text { configuration) }\end{array}$ & $0.27 T$ & $0.27 \mathrm{~T}$ & $0.27 \mathrm{~T}$ & $0.27 T$ & $0.27 \mathrm{~T}$ & $0.27 T$ & $0.025 T$ \\
\hline $\begin{array}{l}1 \\
2 \\
3 \\
3 A \\
3 B^{C} \\
3 C \\
3 D \\
3 E \\
4 \\
4 A \\
4 B \\
5\end{array}$ & $\begin{array}{l}\downarrow \\
.13 T \\
\text { (a) } \\
\text { (a) } \\
\text { (a) } \\
.32 T\end{array}$ & $\begin{array}{l}\downarrow \\
.13 T \\
(a) \\
\text { (a) } \\
\text { (a) } \\
.32 T\end{array}$ & $\begin{array}{l}\downarrow \\
.13 T \\
.32 T \\
.32 T \\
.30 T \\
(a)\end{array}$ & $\begin{array}{l}\downarrow \\
\text { (a) } \\
.32 T \\
.32 T \\
(a) \\
\text { (a) }\end{array}$ & $\begin{array}{l}\text { (a) } \\
\text { (a) } \\
.32 T \\
\mid \\
1 \\
\text { (a) } \\
.32 \mathrm{~T} \\
.32 \mathrm{~T} \\
(\mathrm{a}) \\
\text { (a) }\end{array}$ & $\begin{array}{l}\downarrow \\
.13 \mathrm{~T} \\
\text { (b) } \\
\text { (a) } \\
\text { (a) } \\
.32 \mathrm{~T}\end{array}$ & $\begin{array}{l}(\mathrm{a}) \\
.0255 \mathrm{~T} \\
.026 \mathrm{~T} \\
.019 \mathrm{~T} \\
.019 \mathrm{~T} \\
.0285 \mathrm{~T} \\
.031 \mathrm{~T} \\
.028 \mathrm{~T} \\
.026 \mathrm{~T} \\
.026 \mathrm{~T} \\
.0285 \mathrm{~T} \\
.030 \mathrm{~T}\end{array}$ \\
\hline
\end{tabular}

adenotes no change from baseline configuration.

$b_{\text {Denotes }}$ ring number 6 elimiated from configuration.

${ }^{C}$ Configuration changes from number $3 A$ to $3 B$ was reduction in cathode length, which required repositioning cathode magnet to maintain field strength at orifice.

TABLE III. - GRID SPECIFICATIONS

\begin{tabular}{|c|c|c|}
\hline \multirow[t]{2}{*}{ Design parameters } & \multicolumn{2}{|c|}{ Ion extraction assembly } \\
\hline & $\begin{array}{c}\text { Ring-cusp/J-series, } \\
\text { 2-grid }\end{array}$ & $\begin{array}{l}\text { Modified J-series, } \\
2 \text {-grid }\end{array}$ \\
\hline \multicolumn{3}{|c|}{ Screen grid. } \\
\hline $\begin{array}{l}\text { Hole diameter, cm } \\
\text { Center-to-center spacing, cm }\end{array}$ & $\begin{array}{r}0.190 \\
\text { Hexagonal }\end{array}$ & $\begin{array}{l}0.190 \\
.2202\end{array}$ \\
\hline \multicolumn{3}{|c|}{ Accelerator grid. } \\
\hline $\begin{array}{l}\text { Hole diameter, cm } \\
\text { Center-to-center spacing, cm } \\
\text { Screen-accelerator spacing, } \mathrm{cm} \\
\text { Minimum total voltage at } \\
2 \mathrm{~A} \text { beam current ( } \mathrm{Hg} \text { ions), } \mathrm{V} \\
\text { Dish depth, cm } \\
\text { (Radius of curvature, } \mathrm{m} \text { ) }\end{array}$ & $\begin{array}{r}.1143 \\
.220 \\
.066 \\
1320 \\
2.18 \\
.50\end{array}$ & $\begin{array}{r}.1143 \\
.220 \\
.066 \\
1320 \\
2.18 \\
.50\end{array}$ \\
\hline
\end{tabular}


TABLE IV. - RING-CUSP DISCHARGE CHAMBER PERFORMANCE, XENON PROPELLANT

\begin{tabular}{|c|c|c|c|c|}
\hline $\begin{array}{c}\text { Thruster } \\
\text { configuration }\end{array}$ & $\begin{array}{c}\text { Beam } \\
\text { current, } \\
\mathrm{A}\end{array}$ & $\begin{array}{c}\text { Discharge } \\
\text { voltage, } \\
\mathrm{V}\end{array}$ & $\begin{array}{c}\text { Discharge } \\
\text { power per } \\
\text { beam ampere, } \\
\text { W/A }\end{array}$ & $\begin{array}{c}\text { Discharge } \\
\text { chamber } \\
\text { propellant } \\
\text { efficiency }\end{array}$ \\
\hline 1 & 2.74 & 33.3 & 138 & 0.903 \\
$1 \mathrm{~A}$ & 2.03 & 35.8 & 172 & .897 \\
2 & 3.96 & 32.6 & 119 & .896 \\
$3 \mathrm{C}$ & 2.43 & 35.3 & 154 & .908 \\
$3 \mathrm{D}$ & 2.80 & 35.2 & 138 & .916 \\
$3 \mathrm{E}$ & 2.42 & 30.1 & 160 & .899 \\
$4 \mathrm{~B}$ & 3.42 & 33.0 & 152 & .884 \\
\hline
\end{tabular}

TABLE V. - RING-CUSP DISCHARGE CHAMBER

PERFORMANCE, XENON PROPELLANT (REF. 13)

\begin{tabular}{|c|c|c|c|}
\hline $\begin{array}{c}\text { Beam } \\
\text { Current, } \\
A\end{array}$ & $\begin{array}{c}\text { Discharge } \\
\text { voltage, } \\
V\end{array}$ & $\begin{array}{c}\text { Discharge } \\
\text { power per } \\
\text { beam } \\
\text { ampere, } \\
\text { W/A }\end{array}$ & $\begin{array}{c}\text { Corrected } \\
\text { discharge chamber } \\
\text { propel lant } \\
\text { efficiency }\end{array}$ \\
\hline 3.04 & 29.4 & 90.5 & 0.698 \\
3.95 & 32.8 & 91.8 & .909 \\
4.43 & 35.6 & 94.6 & .997 \\
\hline
\end{tabular}

TABLE VI. - DISCHARGE CHAMBER PERFORMANCE COMPARISON, XENON PROPELLANT

\begin{tabular}{|l|c|c|c|c|}
\hline Thruster configuration & $\begin{array}{c}\text { Beam } \\
\text { current, } \\
A\end{array}$ & $\begin{array}{c}\text { Discharge } \\
\text { voltage, } \\
\text { V }\end{array}$ & $\begin{array}{c}\text { Discharge } \\
\text { power per } \\
\text { beam ampere, } \\
\text { W/A }\end{array}$ & $\begin{array}{c}\text { Discharge chamber } \\
\text { propel lant } \\
\text { efficiency }\end{array}$ \\
\hline \multirow{3}{*}{ Ring-cusp number 2 } & 1.90 & 33.9 & 166 & 0.909 \\
& 2.95 & 30.0 & 132 & .922 \\
& 3.96 & 32.6 & 119 & .896 \\
\hline \multirow{3}{*}{ M-8 } & 1.60 & 34.0 & 224 & 0.900 \\
& 2.18 & 36.0 & 181 & .887 \\
& 4.02 & 32.0 & 164 & .900 \\
\hline & 2.44 & 27.9 & 394 & 9.901 \\
& 4.71 & 25.0 & 255 & .948 \\
\hline
\end{tabular}

$a_{4} .1 \mathrm{~cm}$ diameter magnet baffle removed. 
TABLE VII. - DISTRIBUTION OF CURRENTS TO ANODES

\begin{tabular}{|c|c|c|c|c|c|c|c|c|c|c|}
\hline \multirow[t]{2}{*}{$\begin{array}{l}\text { Thruster } \\
\text { configuration }\end{array}$} & \multirow{2}{*}{$\begin{array}{c}\text { Beam } \\
\text { current, } \\
\text { A }\end{array}$} & \multirow{2}{*}{$\begin{array}{c}\text { Discharge } \\
\text { current, } \\
\text { A }\end{array}$} & \multicolumn{6}{|c|}{$\underset{A}{\text { Electron currents to magnet rings, }}$} & \multirow{2}{*}{$\begin{array}{c}\text { Discharge } \\
\text { power per } \\
\text { beam ampere, } \\
\text { W/A }\end{array}$} & \multirow{2}{*}{$\begin{array}{l}\text { Discharge } \\
\text { chamber } \\
\text { propellant } \\
\text { efficiency }\end{array}$} \\
\hline & & & 1 & 2 & 3 & 4 & 5 & 6 & & \\
\hline $1 \mathrm{~A}$ & $\begin{array}{l}1.73 \\
1.93 \\
2.13\end{array}$ & $\begin{array}{r}9.9 \\
11.0 \\
12.8\end{array}$ & - & - & -..- & $\begin{array}{l}0.04 \\
.05 \\
.08\end{array}$ & - & -.-- & $\begin{array}{l}166 \\
167 \\
182\end{array}$ & $\begin{array}{r}0.782 \\
.861 \\
.928\end{array}$ \\
\hline 2 & $\begin{array}{l}2.41 \\
2.70 \\
3.06\end{array}$ & $\begin{array}{l}13.0 \\
14.7 \\
16.5\end{array}$ & ---- & -..- & $-\cdots$ & $\begin{array}{l}0.08 \\
.08 \\
.07\end{array}$ & - & --- & $\begin{array}{l}127 \\
129 \\
135\end{array}$ & $\begin{array}{r}0.778 \\
.860 \\
.937\end{array}$ \\
\hline $3 C$ & $\begin{array}{l}2.08 \\
2.36 \\
2.51\end{array}$ & $\begin{array}{l}10.9 \\
12.3 \\
13.1\end{array}$ & --.- & -..- & --- & $\begin{array}{r}0.04 \\
.04 \\
.04\end{array}$ & - & -.-- & $\begin{array}{l}148 \\
148 \\
151\end{array}$ & $\begin{array}{r}0.798 \\
.892 \\
.933\end{array}$ \\
\hline $3 E$ & $\begin{array}{l}2.11 \\
2.30 \\
2.42\end{array}$ & $\begin{array}{l}13.3 \\
14.4 \\
15.3\end{array}$ & $\begin{array}{l}5.11 \\
5.54 \\
5.76\end{array}$ & $\begin{array}{l}7.19 \\
7.68 \\
8.21\end{array}$ & $\begin{array}{r}0.02 \\
.02 \\
.04\end{array}$ & $-\cdots$ & - & $\begin{array}{l}0.84 \\
.96 \\
1.96\end{array}$ & $\begin{array}{l}156 \\
159 \\
160\end{array}$ & $\begin{array}{r}0.803 \\
.867 \\
.899\end{array}$ \\
\hline $4 B$ & 3.01 & 16.5 & 6.00 & 5.55 & 0.05 & ---- & - & 2.88 & 148 & 0.791 \\
\hline 5 & 2.27 & 17.3 & 0.392 & 13.3 & 0.03 & $-\cdots$ & - & 0 & 225 & 0.941 \\
\hline
\end{tabular}

TABLE VIII. - DISTRIBUTION OF CURRENTS TO ANODES OF CONFIGURATION NUMBER $3 E$

\begin{tabular}{|c|c|c|c|c|c|c|c|c|}
\hline \multirow{2}{*}{$\begin{array}{c}\text { Beam } \\
\text { current, } \\
\text { A }\end{array}$} & \multirow{2}{*}{$\begin{array}{c}\text { Discharge } \\
\text { current, } \\
\text { A }\end{array}$} & \multicolumn{4}{|c|}{ Electron currents to magnet rings, } & \multirow{2}{*}{$\begin{array}{c}\text { Discharge } \\
\text { voltage, } \\
V\end{array}$} & \multirow{2}{*}{$\begin{array}{c}\text { Discharge } \\
\text { power per } \\
\text { beam ampere, } \\
\text { W/A }\end{array}$} & \multirow{2}{*}{$\begin{array}{l}\text { Discharge } \\
\text { chamber } \\
\text { propellant } \\
\text { efficiency }\end{array}$} \\
\hline & & 1 & 2 & 3 to 5 & 6 & & & \\
\hline $\begin{array}{l}1.54 \\
2.06 \\
1.64 \\
1.80 \\
1.94 \\
2.07 \\
2.12 \\
2.23 \\
2.27 \\
1.69 \\
1.82 \\
2.06 \\
2.22 \\
2.38\end{array}$ & $\begin{array}{r}9.8 \\
12.7 \\
10.5 \\
11.7 \\
12.8 \\
14.0 \\
14.8 \\
16.0 \\
17.1 \\
11.4 \\
12.1 \\
13.5 \\
14.6 \\
15.9\end{array}$ & $\begin{array}{l}6.66 \\
8.41 \\
3.52 \\
4.05 \\
4.60 \\
5.10 \\
5.43 \\
5.77 \\
5.93 \\
4.46 \\
4.70 \\
5.43 \\
5.90 \\
6.50\end{array}$ & $\begin{array}{l}(\mathrm{a}) \\
(\mathrm{a}) \\
5.85 \\
6.28 \\
6.76 \\
7.26 \\
7.51 \\
8.07 \\
8.65 \\
6.88 \\
7.39 \\
8.06 \\
8.63 \\
9.27\end{array}$ & $\begin{array}{r}0.51 \\
.77 \\
(a)\end{array}$ & $\begin{array}{l}2.55 \\
2.99 \\
1.26 \\
1.46 \\
1.60 \\
1.81 \\
1.96 \\
2.15 \\
2.57 \\
\text { (a) }\end{array}$ & $\begin{array}{l}30.8 \\
32.2 \\
28.8 \\
29.1 \\
29.8 \\
30.9 \\
31.0 \\
32.7 \\
33.1 \\
28.4 \\
28.6 \\
29.2 \\
29.5 \\
30.1\end{array}$ & $\begin{array}{l}166 \\
167 \\
155 \\
159 \\
168 \\
179 \\
185 \\
201 \\
213 \\
162 \\
162 \\
163 \\
165 \\
171\end{array}$ & $\begin{array}{r}0.597 \\
.790 \\
.770 \\
.832 \\
.873 \\
.906 \\
.920 \\
.940 \\
.979 \\
.657 \\
.704 \\
.784 \\
.837 \\
.892\end{array}$ \\
\hline
\end{tabular}

a Denotes ring at floating potential. 
TABLE IX. - DEMONSTRATED RING-CUSP THRUSTER PERFORMANCE

\begin{tabular}{|c|c|c|c|c|c|c|c|c|c|c|c|c|}
\hline $\begin{array}{l}\text { Ring-cusp } \\
\text { thruster } \\
\text { configuration }\end{array}$ & $\begin{array}{l}\text { Beam } \\
\text { voltage, } \\
\text { VB, } \\
\text { V }\end{array}$ & $\begin{array}{c}\text { Beam } \\
\text { current, } \\
\text { JB, } \\
\text { A }\end{array}$ & $\begin{array}{c}\text { Discharge } \\
\text { voltage, } \\
\text { VD } \\
V\end{array}$ & $\begin{array}{l}\text { Ion beam } \\
\text { production } \\
\text { cost, } \\
\text { W/A }\end{array}$ & $\begin{array}{c}\text { Total } \\
\text { propellant } \\
\text { efficiency }\end{array}$ & $\begin{array}{c}\text { Ion mass } \\
\text { flowrate } \\
\text { correction } \\
\text { factor, } \\
B\end{array}$ & $\begin{array}{l}\text { Thrust } \\
\text { correction } \\
\text { factor, } \\
\alpha\end{array}$ & $\begin{array}{c}\text { Thruster } \\
\text { input } \\
\text { power, } \\
\text { P, } \\
\omega\end{array}$ & $\begin{array}{c}\text { Thrust, } \\
\text { F, } \\
\text { N }\end{array}$ & $\begin{array}{l}\text { Specific } \\
\text { impulse, } \\
\text { Isp, } \\
\text { sec }\end{array}$ & $\begin{array}{l}\mathrm{F} / \mathrm{P}, \\
\mathrm{mn} / \mathrm{kw}\end{array}$ & $\begin{array}{c}\text { Overall } \\
\text { thruster } \\
\text { efficiency }\end{array}$ \\
\hline 1 & $\begin{array}{l}1250 \\
1200 \\
1200 \\
1200\end{array}$ & $\begin{array}{l}2.43 \\
2.67 \\
2.77 \\
2.87\end{array}$ & $\begin{array}{l}32.4 \\
32.4 \\
32.8 \\
33.3\end{array}$ & $\begin{array}{l}138 \\
141 \\
141 \\
143\end{array}$ & $\begin{array}{r}0.787 \\
.854 \\
.879 \\
.898\end{array}$ & $\begin{array}{r}0.975 \\
.962 \\
.955 \\
.941\end{array}$ & $\begin{array}{r}0.985 \\
.978 \\
.973 \\
.965\end{array}$ & $\begin{array}{l}3460 \\
3680 \\
3800 \\
3960\end{array}$ & $\begin{array}{r}0.137 \\
.146 \\
.151 \\
.155\end{array}$ & $\begin{array}{l}3310 \\
3490 \\
3580 \\
3620\end{array}$ & $\begin{array}{l}39.6 \\
39.8 \\
39.6 \\
39.2\end{array}$ & $\begin{array}{r}0.642 \\
.681 \\
.695 \\
.697\end{array}$ \\
\hline 2 & $\begin{array}{l}1320 \\
1320 \\
1350 \\
1350 \\
1350 \\
1320 \\
1620 \\
1620 \\
.1620\end{array}$ & $\begin{array}{l}2.50 \\
2.70 \\
2.95 \\
3.06 \\
3.13 \\
3.64 \\
.3 .81 \\
3.96 \\
4.14\end{array}$ & $\begin{array}{l}28.8 \\
29.0 \\
30.0 \\
30.5 \\
31.2 \\
30.2 \\
31.2 \\
32.6 \\
33.0\end{array}$ & $\begin{array}{l}127 \\
129 \\
132 \\
134 \\
138 \\
114 \\
116 \\
119 \\
119\end{array}$ & $\begin{array}{l}0.779 \\
.832 \\
.892 \\
.907 \\
.918 \\
.816 \\
.849 \\
.876 \\
.904\end{array}$ & $\begin{array}{l}0.979 \\
.967 \\
.950 \\
.930 \\
.920 \\
.973 \\
.966 \\
.960 \\
.947\end{array}$ & $\begin{array}{r}0.987 \\
.981 \\
.971 \\
.959 \\
.953 \\
.984 \\
.980 \\
.976 \\
.969\end{array}$ & $\begin{array}{l}3700 \\
3990 \\
4450 \\
4630 \\
4750 \\
6460 \\
6720 \\
7000 \\
7330\end{array}$ & $\begin{array}{r}0.145 \\
.155 \\
.170 \\
.174 \\
.177 \\
.233 \\
.243 \\
.252 \\
.261\end{array}$ & $\begin{array}{l}3370 \\
3570 \\
3830 \\
3850 \\
3870 \\
3890 \\
4040 \\
4150 \\
4260\end{array}$ & $\begin{array}{l}39.2 \\
38.9 \\
38.1 \\
37.6 \\
37.3 \\
36.3 \\
36.1 \\
35.9 \\
35.9\end{array}$ & $\begin{array}{r}0.647 \\
.681 \\
.716 \\
.710 \\
.708 \\
.694 \\
.715 \\
.731 \\
.744\end{array}$ \\
\hline $3 E$ & $\downarrow$ & $\begin{array}{l}2.11 \\
2.30 \\
2.42 \\
2.51\end{array}$ & $\begin{array}{l}29.4 \\
30.1 \\
30.1 \\
30.1\end{array}$ & $\begin{array}{l}156 \\
159 \\
160 \\
165\end{array}$ & $\begin{array}{r}0.773 \\
.834 \\
.948 \\
.887\end{array}$ & $\begin{array}{r}0.947 \\
.966 \\
.969 \\
.937\end{array}$ & $\begin{array}{r}0.985 \\
.980 \\
.969 \\
.963\end{array}$ & $\begin{array}{l}2980 \\
3250 \\
3430 \\
3560\end{array}$ & $\begin{array}{r}0.117 \\
.127 \\
.133 \\
.137\end{array}$ & $\begin{array}{l}3209 \\
3440 \\
3580 \\
3590\end{array}$ & $\begin{array}{l}39.3 \\
39.1 \\
38.7 \\
38.3\end{array}$ & $\begin{array}{r}0.619 \\
.660 \\
.669 \\
.676\end{array}$ \\
\hline $4 B$ & $\left.\right|^{1720}$ & $\begin{array}{l}3.01 \\
3.15 \\
3.31 \\
3.42 \\
3.66\end{array}$ & $\begin{array}{l}33.1 \\
33.0 \\
32.9 \\
33.0 \\
33.3 \\
\end{array}$ & $\begin{array}{l}148 \\
149 \\
151 \\
152 \\
158 \\
\end{array}$ & $\begin{array}{l}0.766 \\
.799 \\
.833 \\
.857 \\
.900 \\
\end{array}$ & $\begin{array}{r}0.980 \\
.975 \\
.968 \\
.963 \\
.945 \\
\end{array}$ & $\begin{array}{r}0.988 \\
.985 \\
.981 \\
.978 \\
.968 \\
\end{array}$ & $\begin{array}{l}5710 \\
5980 \\
6290 \\
6510 \\
6990 \\
\end{array}$ & $\begin{array}{r}0.199 \\
.208 \\
.218 \\
.225 \\
.238 \\
\end{array}$ & $\begin{array}{l}3780 \\
3930 \\
4090 \\
4190 \\
4360 \\
\end{array}$ & $\begin{array}{l}34.9 \\
34.8 \\
34.6 \\
34.5 \\
34.0\end{array}$ & $\begin{array}{r}0.647 \\
.671 \\
.694 \\
.720 \\
.727 \\
\end{array}$ \\
\hline
\end{tabular}


TABLE X. - SUMMARY OF MASS SPECTROMETRY

\begin{tabular}{|c|c|c|c|c|c|c|c|}
\hline \multirow[t]{2}{*}{$\begin{array}{l}\text { Thruster } \\
\text { configuration }\end{array}$} & \multicolumn{2}{|c|}{$\begin{array}{c}\text { Propellant flow, } \\
\text { eq. A }\end{array}$} & \multirow{2}{*}{$\begin{array}{c}\text { Beam } \\
\text { current, } \\
\text { A }\end{array}$} & \multirow{2}{*}{$\begin{array}{l}\text { Discharge } \\
\text { voltage, } \\
\text { V }\end{array}$} & \multirow{2}{*}{$\begin{array}{c}\text { Discharge } \\
\text { power per } \\
\text { beam ampere, } \\
\text { W/A }\end{array}$} & \multirow{2}{*}{$\begin{array}{l}\text { Discharge } \\
\text { chamber } \\
\text { propellant } \\
\text { efficiency }\end{array}$} & \multirow{2}{*}{$\begin{array}{c}\mathrm{I}^{++} \mathrm{I}^{+} \\
\text {at } \\
\text { centerline }\end{array}$} \\
\hline & Main & Cathode & & & & & \\
\hline 1 & 1.93 & 0.10 & 1.95 & 37.7 & 140 & 0.902 & 0.102 \\
\hline $1 A$ & 1.67 & 0.47 & 2.01 & 35.2 & 175 & 0.901 & 0.066 \\
\hline 2 & $\begin{array}{l}1.67 \\
2.67\end{array}$ & $\begin{array}{r}0.33 \\
.33\end{array}$ & $\begin{array}{l}1.90 \\
2.95\end{array}$ & $\begin{array}{l}33.9 \\
30.0\end{array}$ & $\begin{array}{l}166 \\
132\end{array}$ & $\begin{array}{r}0.909 \\
.922\end{array}$ & $\begin{array}{r}0.064 \\
.110\end{array}$ \\
\hline $3 C$ & $\begin{array}{l}1.73 \\
2.20 \\
2.67\end{array}$ & $\begin{array}{r}0.32 \\
.32 \\
.32\end{array}$ & $\begin{array}{l}1.94 \\
2.36 \\
2.82\end{array}$ & $\begin{array}{l}37.5 \\
35.1 \\
34.7\end{array}$ & $\begin{array}{l}168 \\
148 \\
157\end{array}$ & $\begin{array}{r}0.901 \\
.890 \\
.892\end{array}$ & $\begin{array}{r}0.067 \\
.067 \\
.087\end{array}$ \\
\hline $3 E$ & $\begin{array}{l}1.73 \\
2.20 \\
2.93\end{array}$ & $\begin{array}{r}0.32 \\
.32 \\
.32\end{array}$ & $\begin{array}{l}2.03 \\
2.42 \\
2.86\end{array}$ & $\begin{array}{l}30.5 \\
30.1 \\
25.9\end{array}$ & $\begin{array}{l}175 \\
160 \\
174\end{array}$ & $\begin{array}{r}0.917 \\
.899 \\
.828\end{array}$ & $\begin{array}{r}0.132 \\
.117 \\
.100\end{array}$ \\
\hline
\end{tabular}




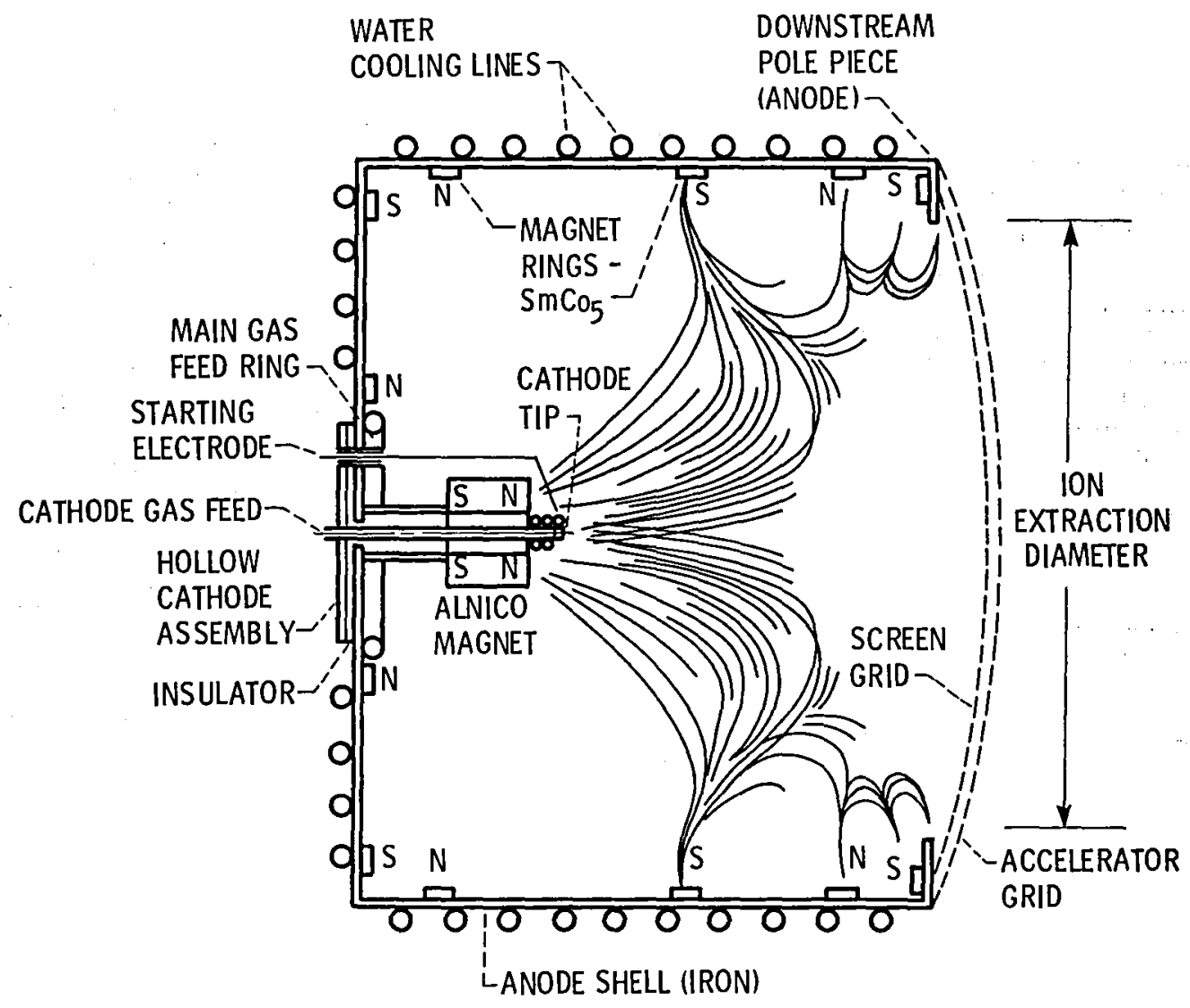

(a) Ring-cusp design (from ref, 13).

Figure 1. - Cross section of 30-centimeter, xenon ion thrusters. 


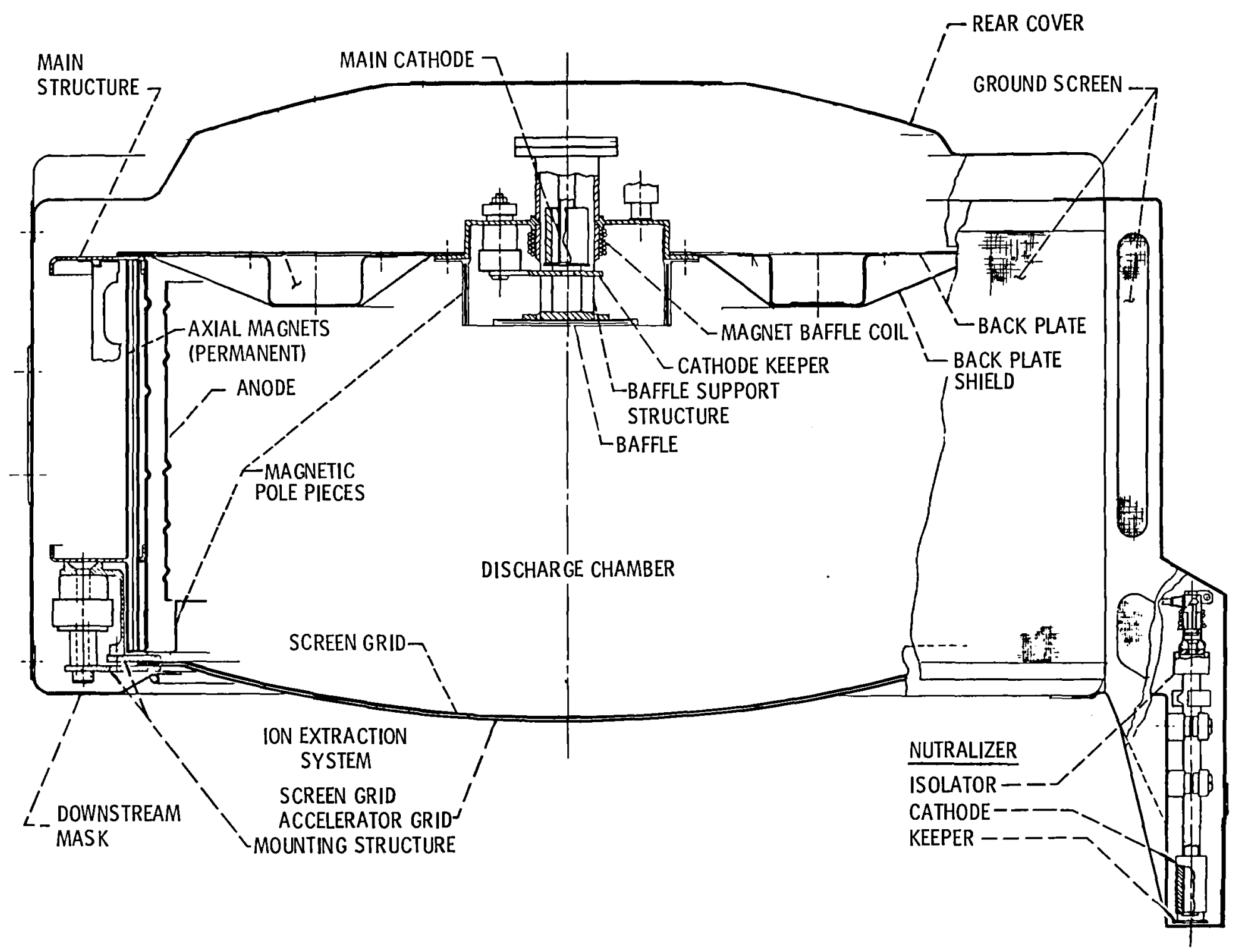

(b) J-series design.

Figure 1. - Concluded. 


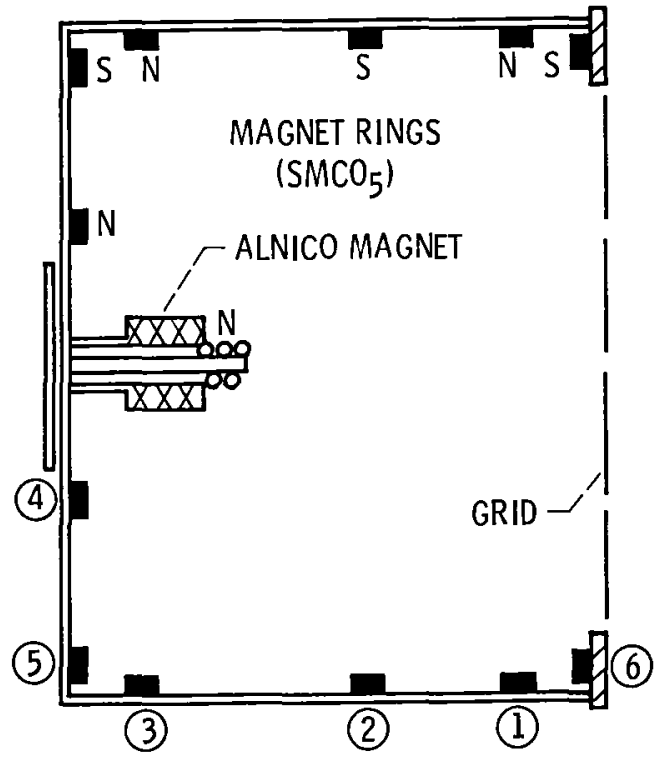

Figure 2. - Ring-cusp configuration 1.

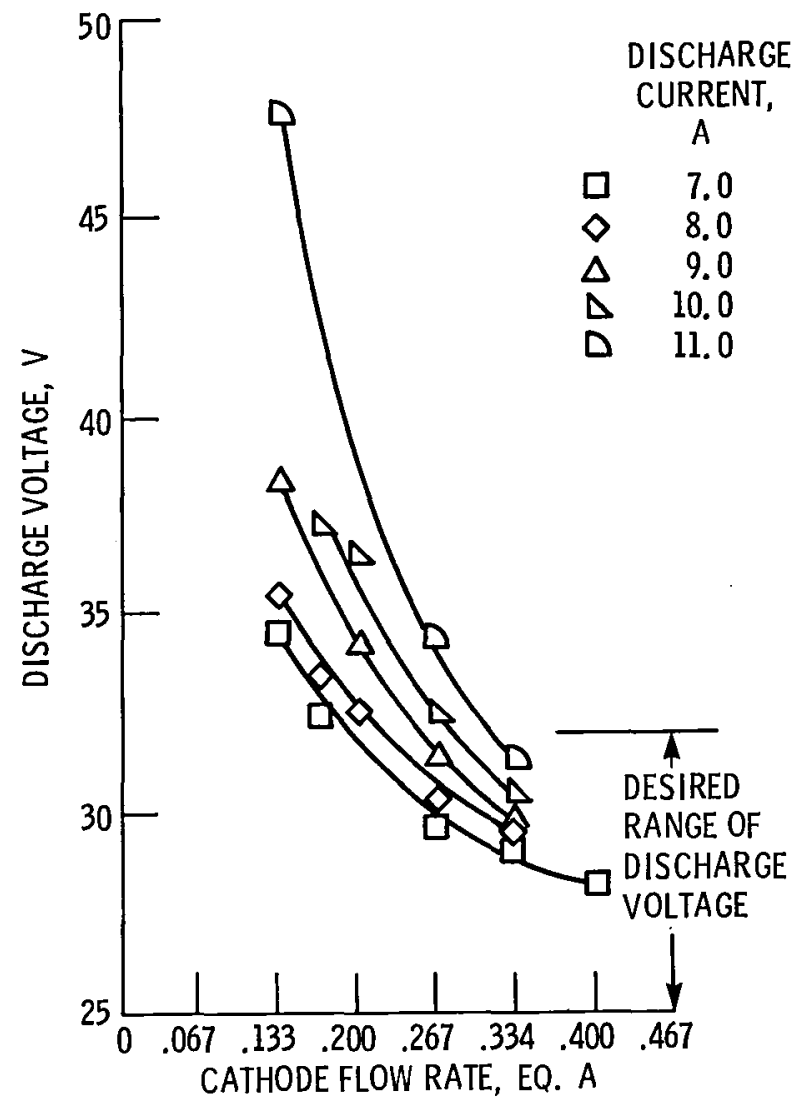

Figure 3. - Ring-cusp configuration 3 discharge voltage dependence on cathode flow rate. $1.60 \mathrm{~A}$ main flow rate xenon propellant. 


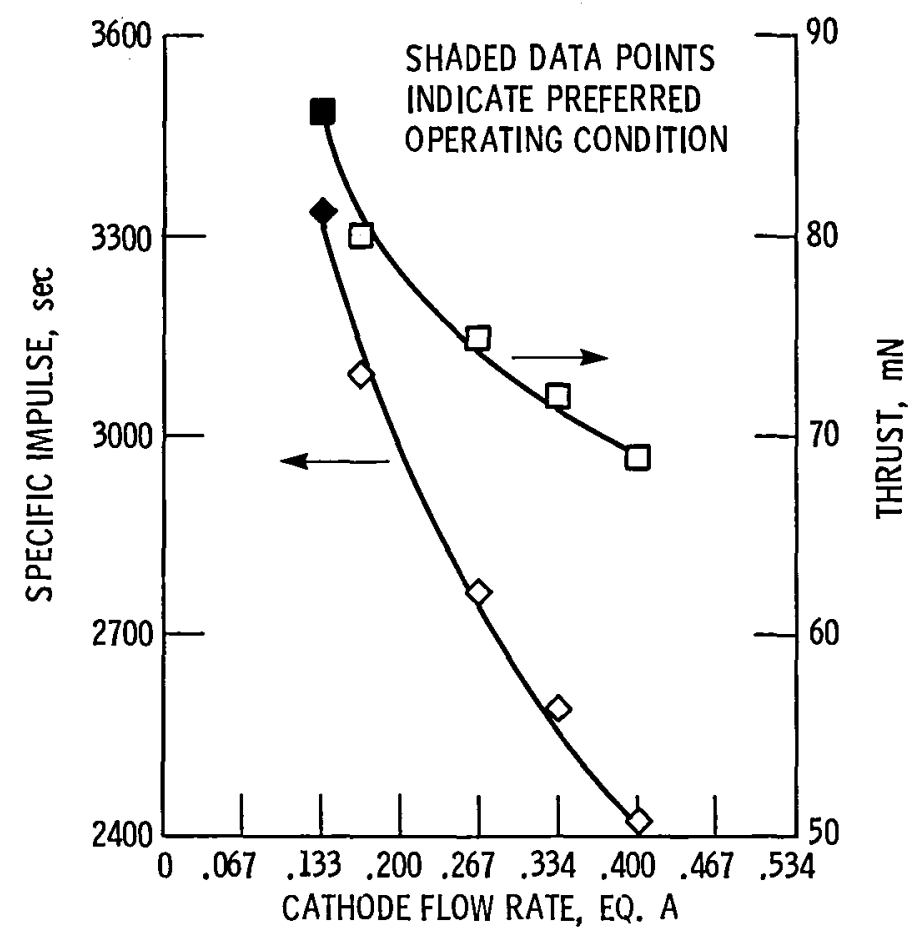

Figure 4. - Ring-cusp configuration 3 specific impulse and thrust sensitivity to cathode flow rate. $7.0 \mathrm{~A}$ discharge current; $1.6 \mathrm{~A}$ main flow rate.

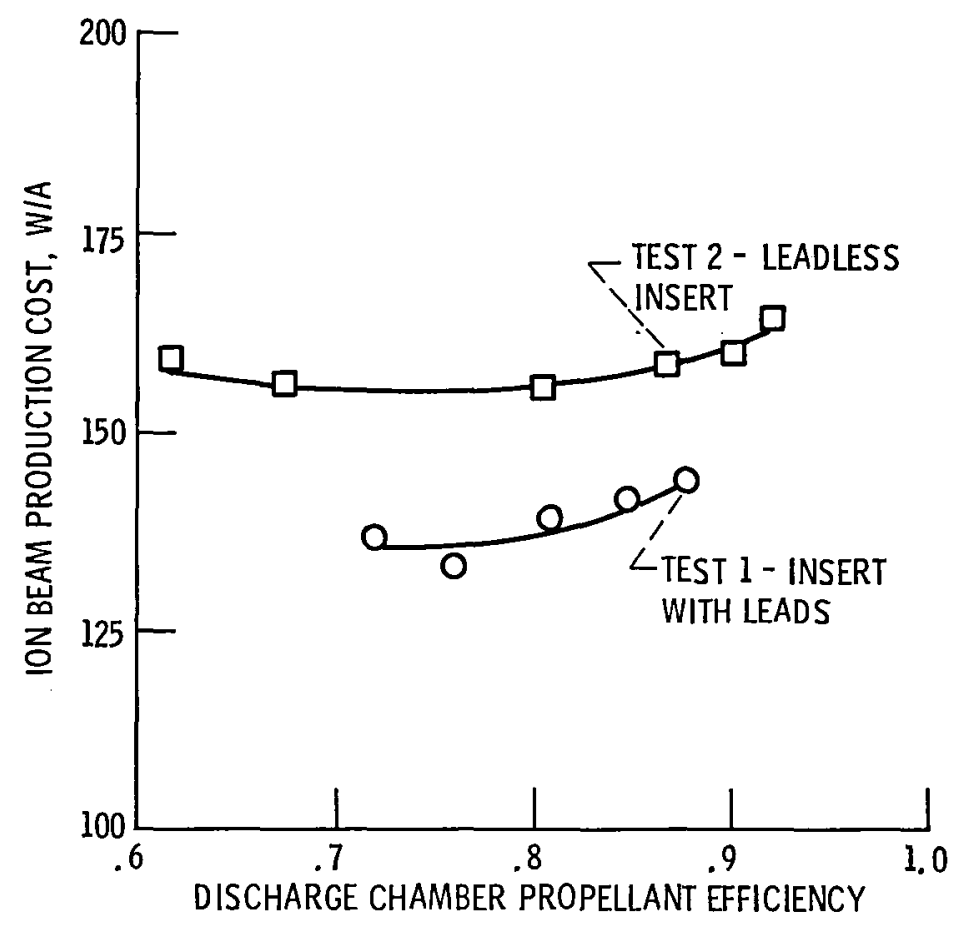

Figure 5. - Effect of cathode insert assembly procedures. 2.52 A total xenon flow rate; configuration $3 E$. 


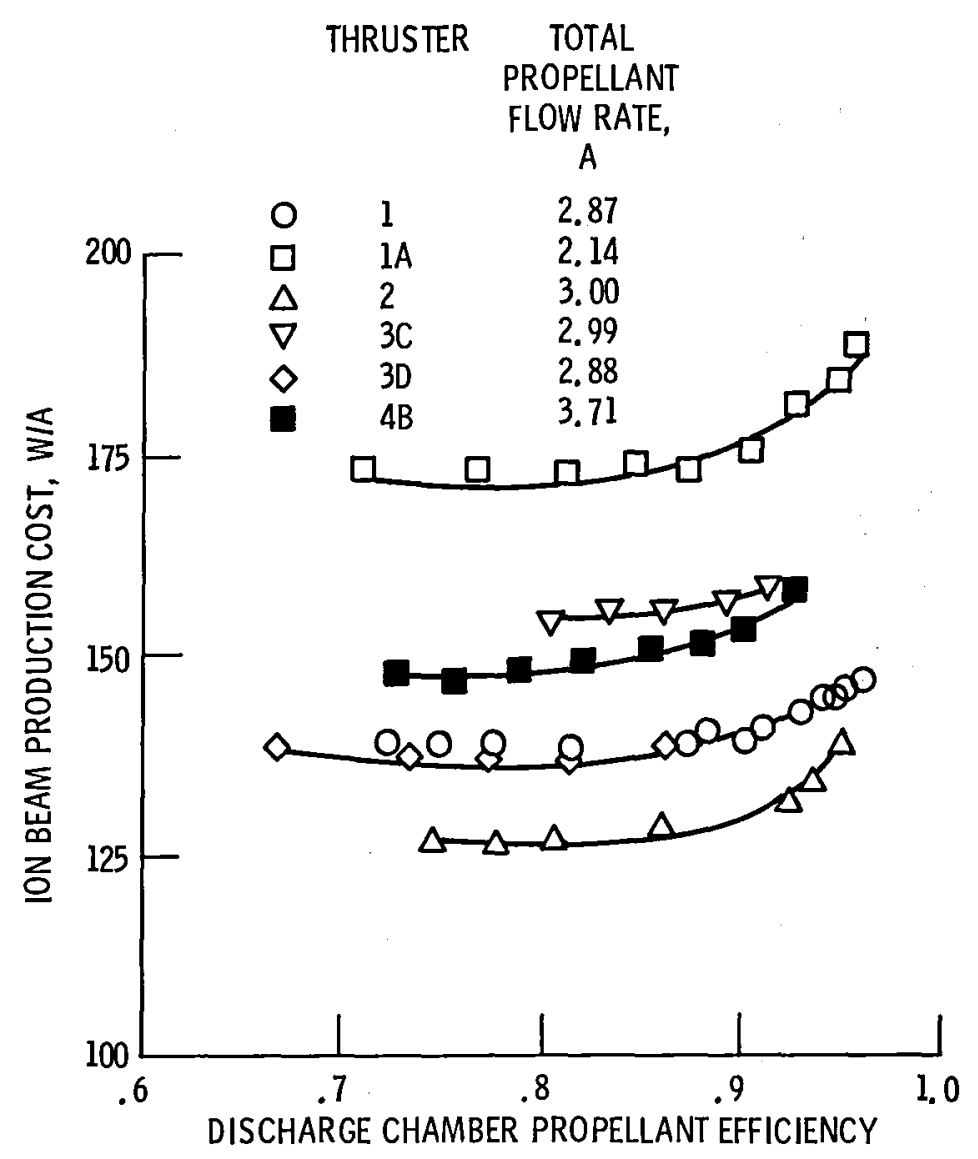

Figure 6. - Effect of thruster configuration on performance.

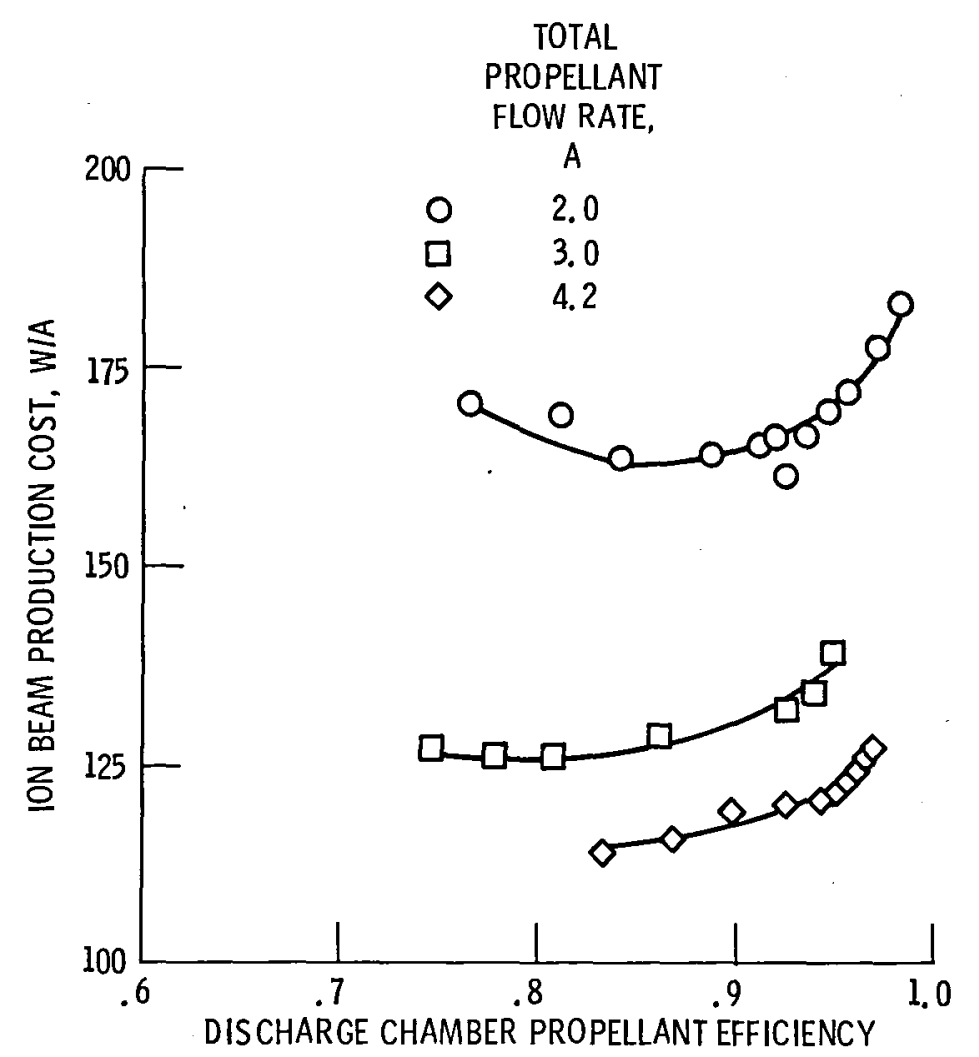

Figure 7. - Ring-cusp configuration 2 performance. 


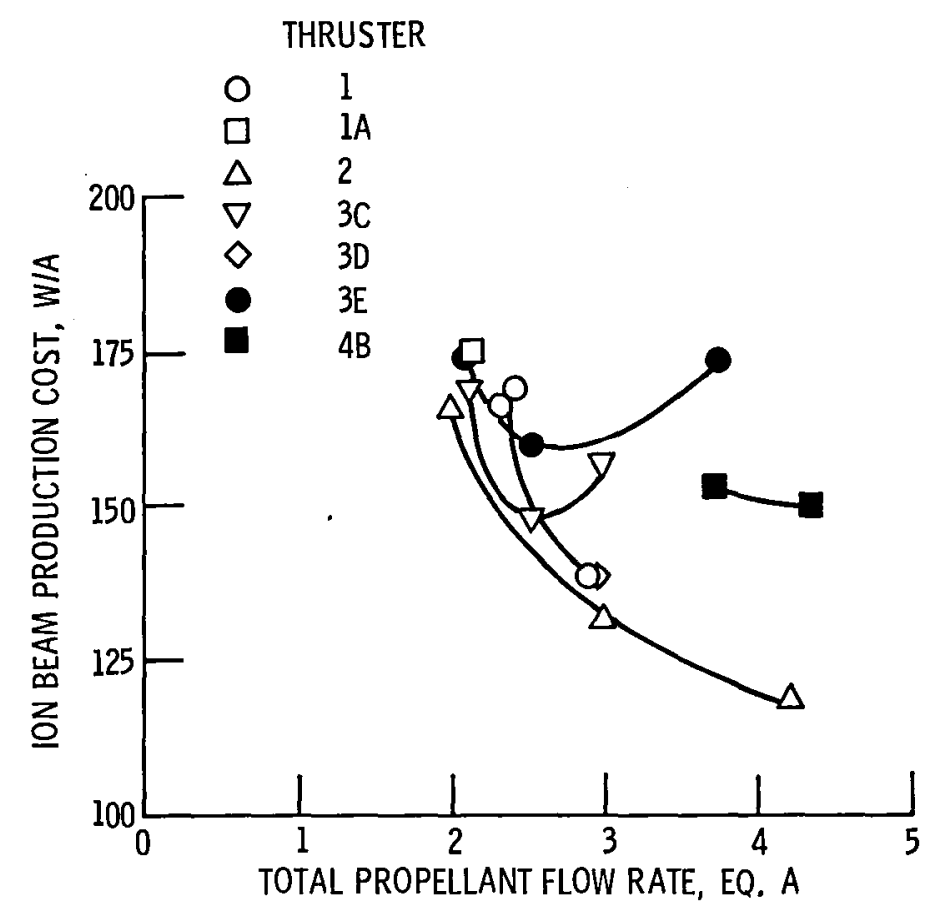

Figure 8. - Throttling performance at near $90 \%$ discharge chamber propellant efficiency.

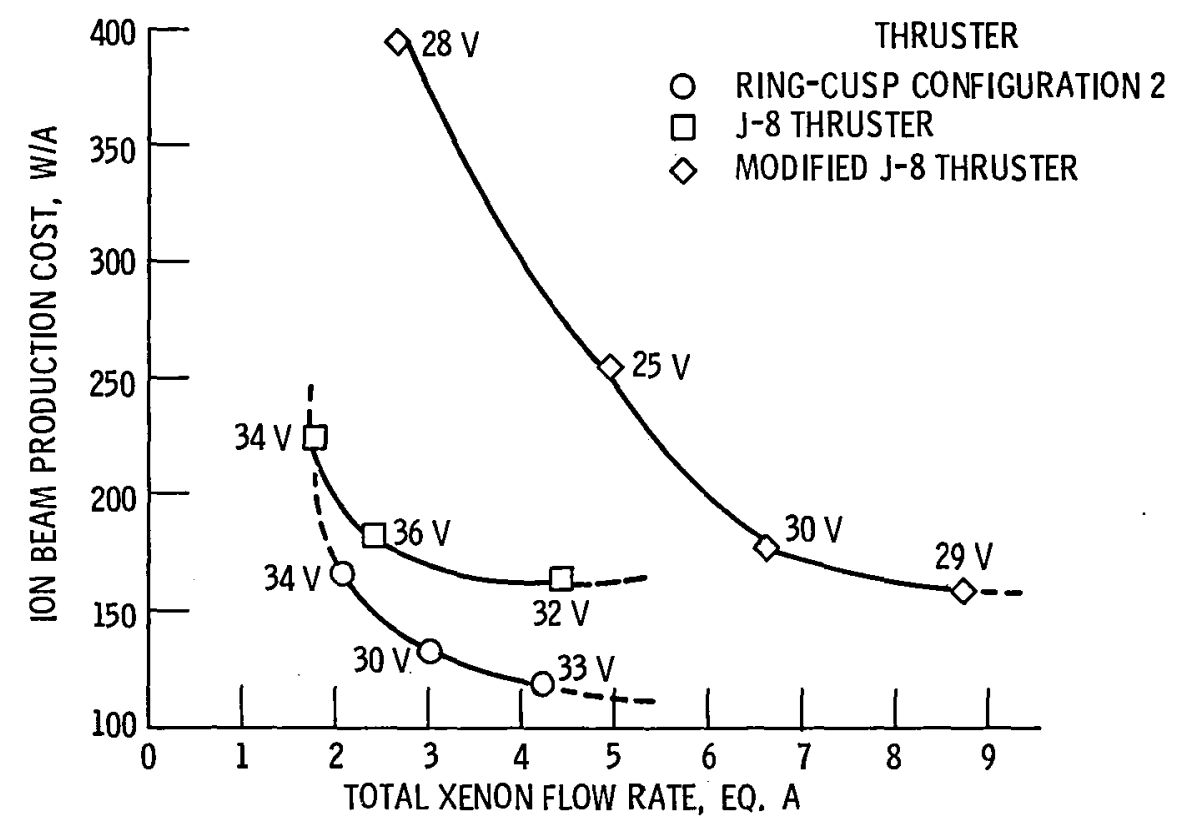

Figure 9. - Throttling comparison, at near $90 \%$ discharge chamber propellant efficiency. Discharge voltages are indicated. 


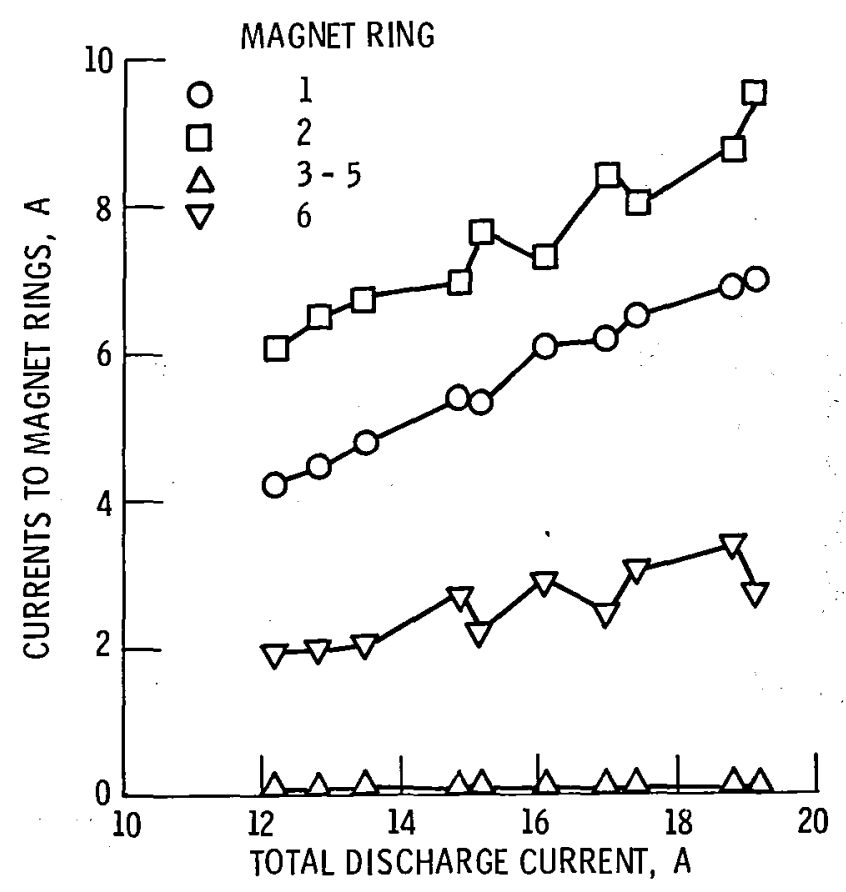

Figure 10. - Distribution of electron currents to magnet rings for configuration $3 E$. $2.52 \mathrm{~A}$ total propellant flow rate.

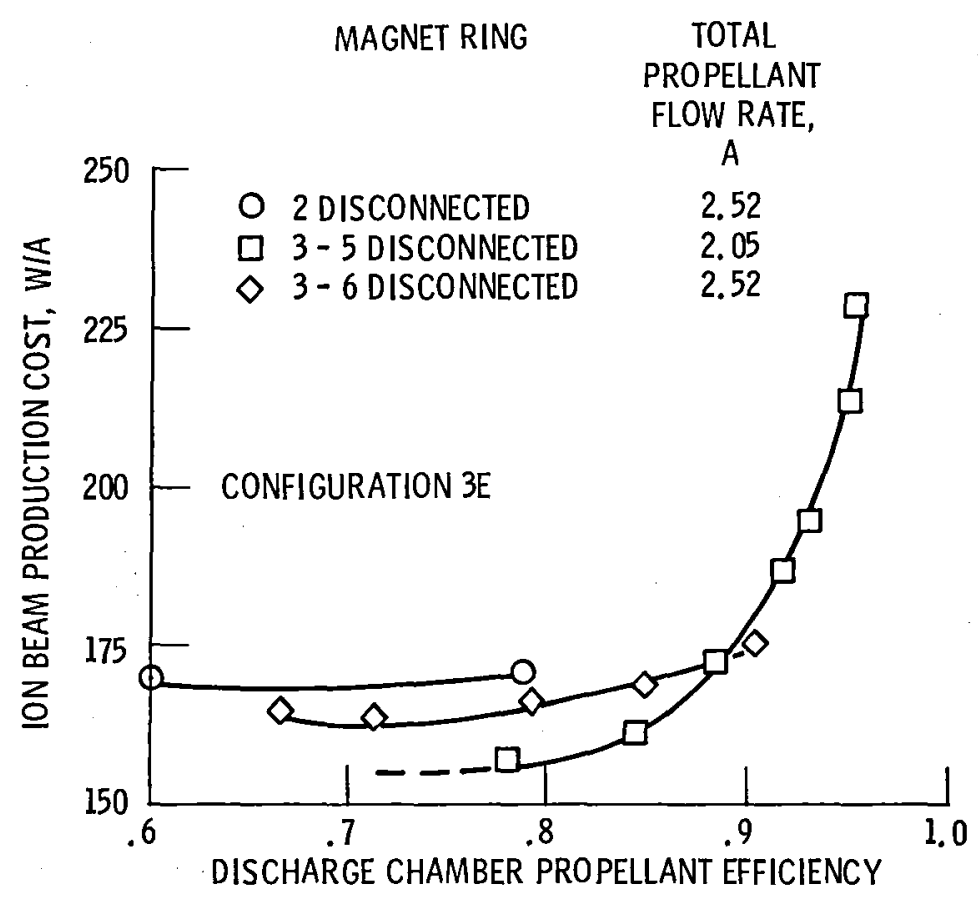

Figure 11. - Effect of anode current distribution on performance. 


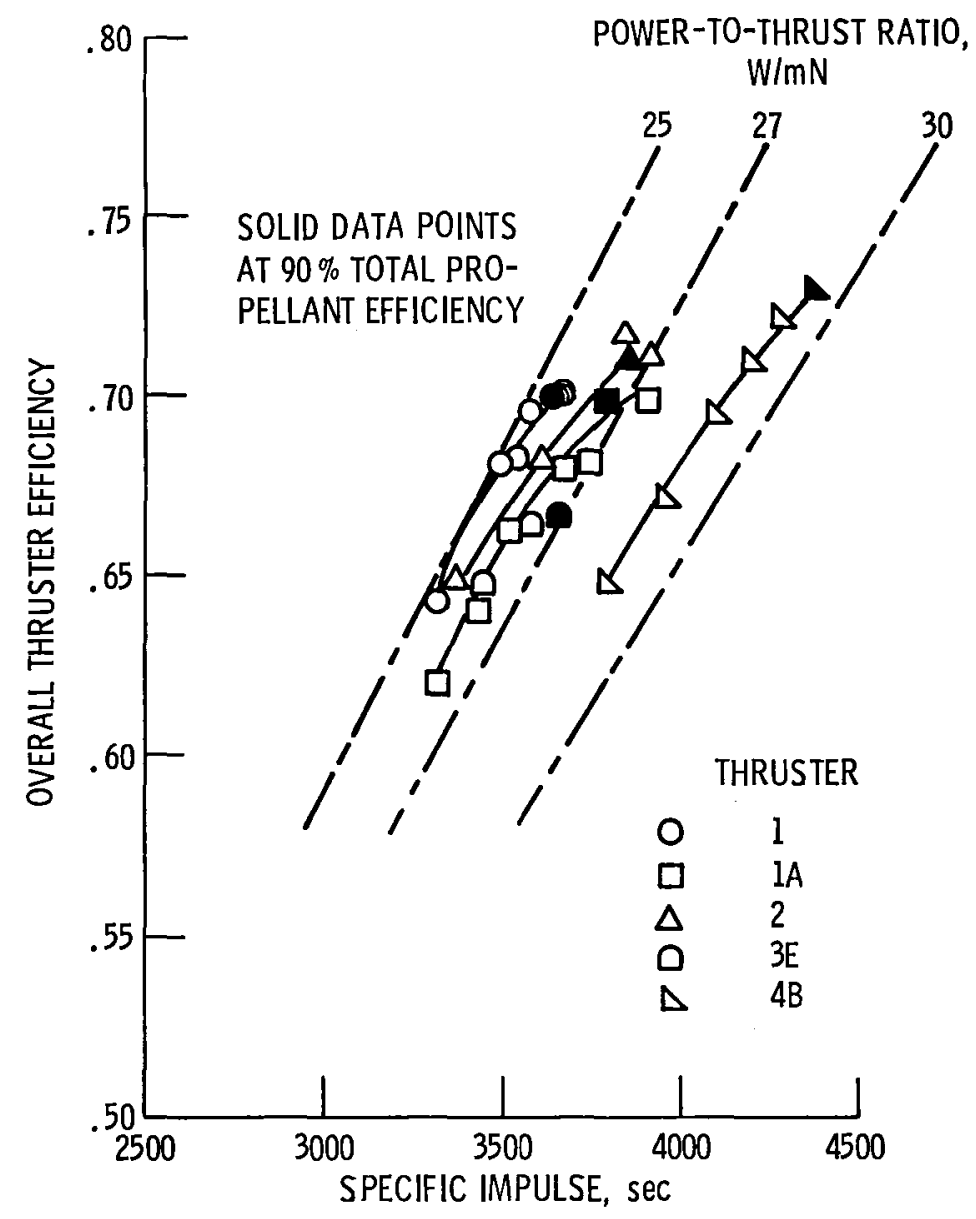

Figure 12. - Demonstrated ring-cusp thruster efficiencies as a function of specific impulse.

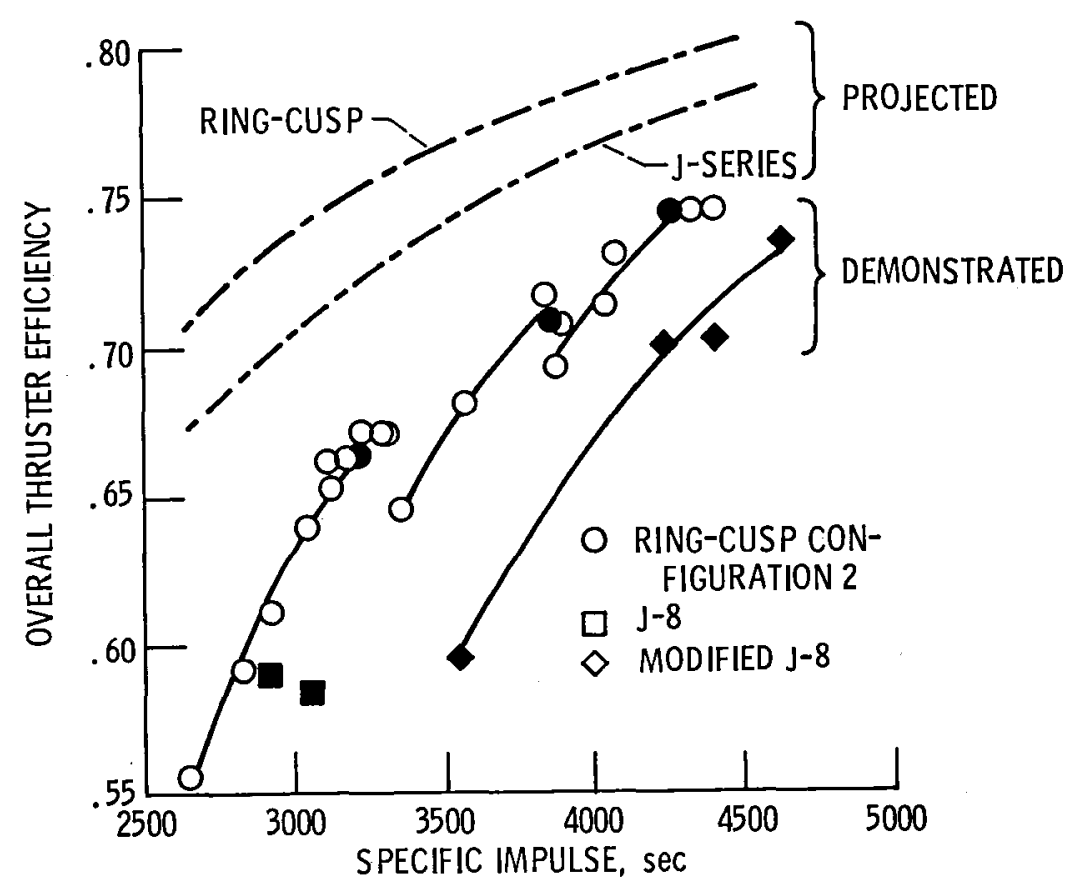

Figure 13. - Ring-cusp configuration 2, J-8 and modified $\mathrm{J}-8$ thruster performance comparison. Solid data points at $90 \%$ total propellant efficiency. 


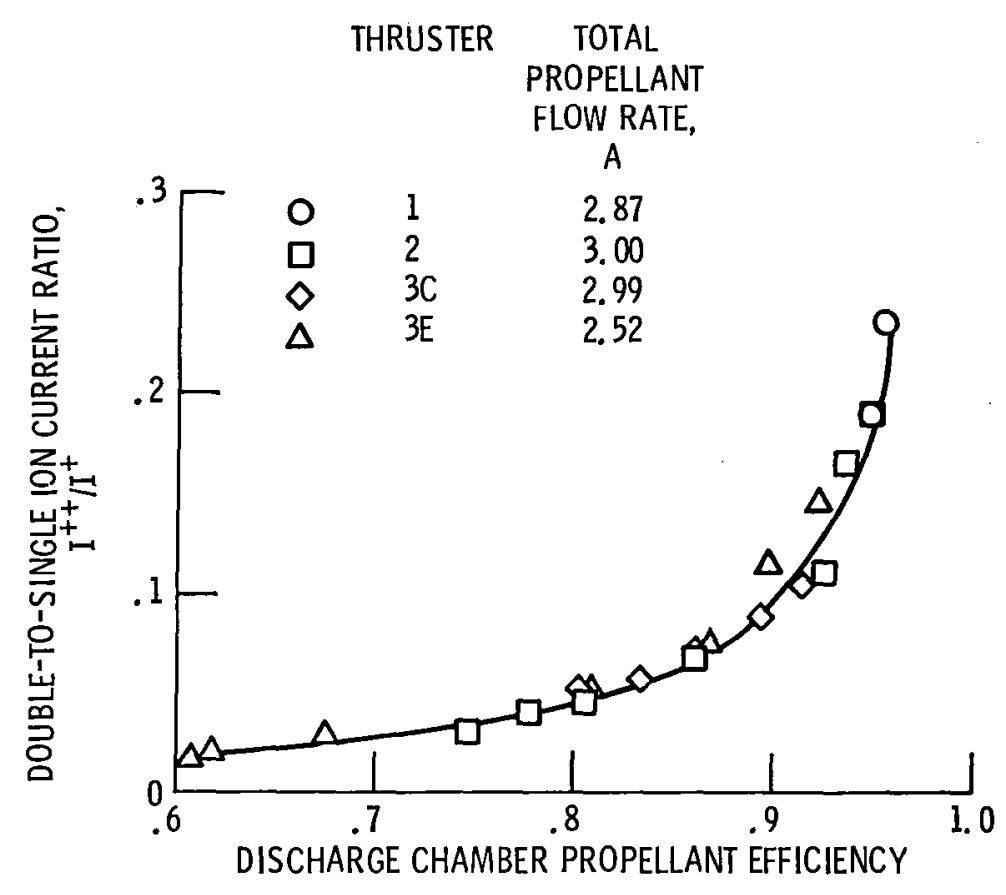

Figure 14. - Effect of ring-cusp thruster geometry on double-to-single ion current ratio.

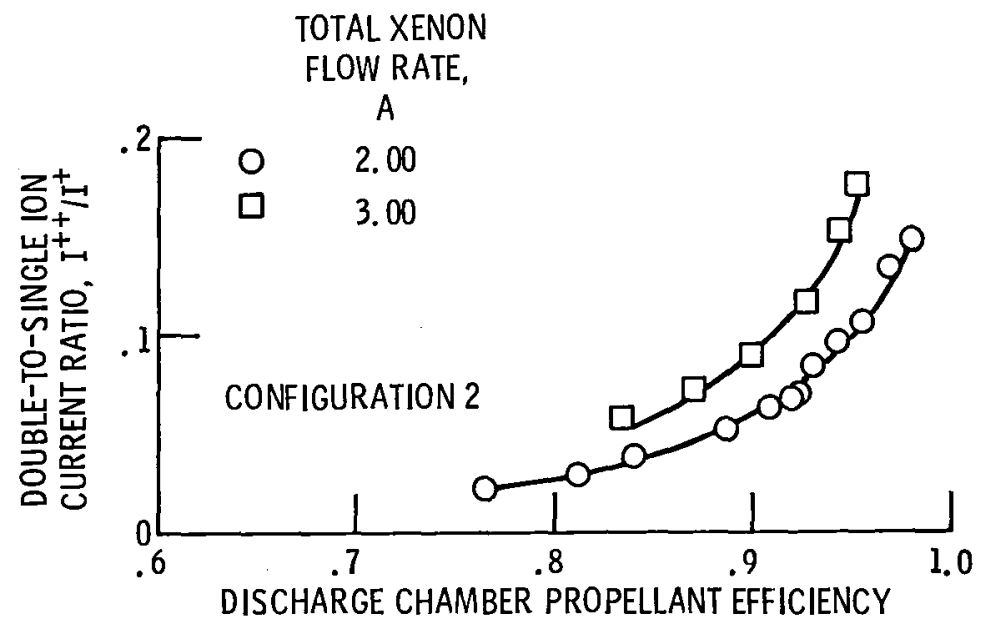

Figure 15. - Double-to-single ion current ratio sensitivity to beam current. 


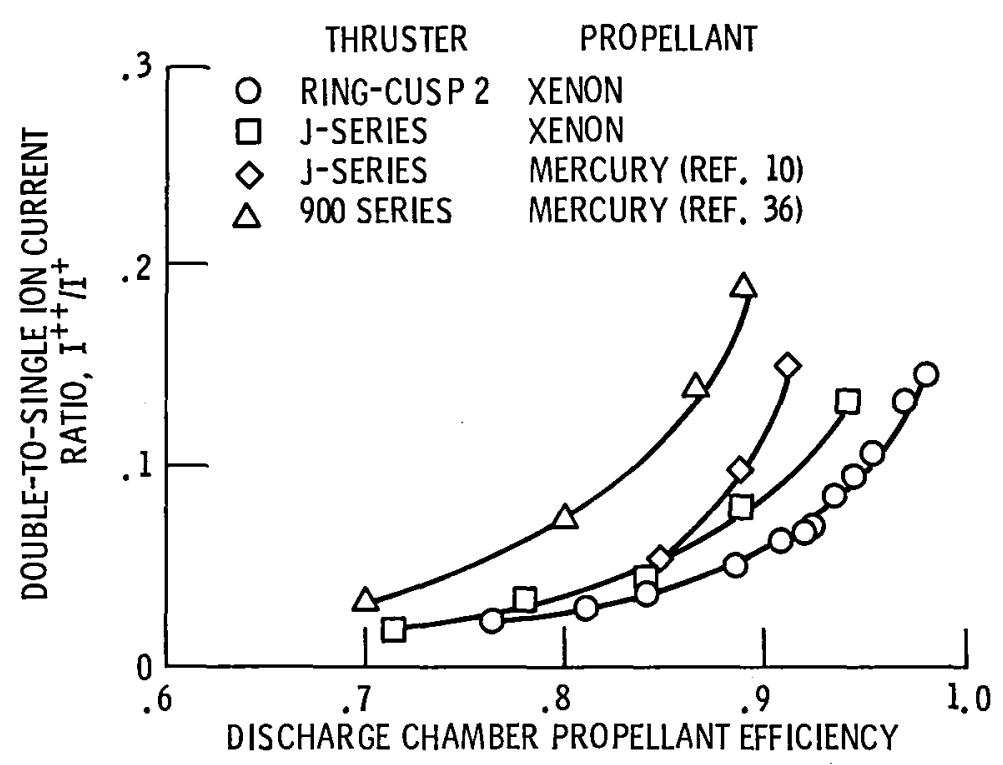

Figure 16. - Double-to-single ion current ratio sensitivity to thruster and propellant type. 


\begin{tabular}{|c|c|c|}
\hline $\begin{array}{l}\text { 1. Report No. NASA TM-87338 } \\
\text { AIAA-86-1392 }\end{array}$ & 2. Government Accession No. & 3. Recipient's Catalog No. \\
\hline \multirow{3}{*}{\multicolumn{2}{|c|}{$\begin{array}{l}\text { 4. Title and Subtitle } \\
\text { Performance Characteristics of Ring-Cusp } \\
\text { Thrusters With Xenon Propellant }\end{array}$}} & 5. Report Date \\
\hline & & \\
\hline & & $\begin{array}{l}\text { 6. Performing Organization Code } \\
506-42-32\end{array}$ \\
\hline \multirow{3}{*}{\multicolumn{2}{|c|}{$\begin{array}{l}\text { 7. Author(s) } \\
\text { Michael J. Patterson }\end{array}$}} & 8. Performing Organization Report No. \\
\hline & & $E-3085$ \\
\hline & & 10. Work Unit No. \\
\hline \multirow{3}{*}{\multicolumn{2}{|c|}{$\begin{array}{l}\text { 9. Performing Organization Name and Address } \\
\text { National Aeronautics and Space Administration } \\
\text { Lewis Research Center } \\
\text { Cleveland, Ohto } 44135\end{array}$}} & \\
\hline & & 11. Contract or Grant No. \\
\hline & & 13. Type of Report and Period Covered \\
\hline \multicolumn{2}{|l|}{ 12. Sponsoring Agency Name and Address } & Technical Memorandum \\
\hline \multicolumn{2}{|c|}{$\begin{array}{l}\text { National Aeronautics and Space Administration } \\
\text { Washington, D.C. } 20546\end{array}$} & 14. Sponsoring Agency Code \\
\hline \multicolumn{3}{|c|}{$\begin{array}{l}\text { 15. Supplementary Notes } \\
\text { Prepared for the 22nd Joint Propulsion Conference cosponsored by the AIAA, ASME, } \\
\text { SAE, and ASEE, Huntsville, Alabama, June 16-18, } 1986 \text {. }\end{array}$} \\
\hline \multicolumn{3}{|c|}{$\begin{array}{l}\text { 16. Abstract } \\
\text { The performance characteristics and operating envelope of several } 30 \text {-cm ring-cusp } \\
\text { ion thrusters with xenon propellant were investigated. Results indicate a strong } \\
\text { performance dependence on the discharge chamber boundary magnetic fields and } \\
\text { resultant distribution of electron currents. Significant improvements in dis- } \\
\text { charge chamber performance over J-series divergent-field thrusters was achieved } \\
\text { for large throttling ranges, which translate into reduced cathode emission cur- } \\
\text { rents and reduced power dissipation which should be of significant benefit for } \\
\text { operation at thruster power levels in excess of } 10 \mathrm{~kW} \text {. Mass spectrometry of the } \\
\text { ion beam was documented for both the ring-cusp and J-series thrusters with xenon } \\
\text { propellant for determination of overall thruster efficiency, and lifetime. Based } \\
\text { on the lower centerline values of doubly charged ions in the ion beam and the } \\
\text { lower operating discharge voltage, the screen grid erosion rate of the ring-cusp } \\
\text { thruster is expected to be lower than the divergent-field J-series thruster by a } \\
\text { factor of } 2 \text {. }\end{array}$} \\
\hline 17. Key Words (Suggested by Author(s)) & & 18. Distribution Statement \\
\hline \multicolumn{2}{|c|}{$\begin{array}{l}\text { Ion thrusters; Ring-cusp; } \\
\text { Electrostatic propulsion; } \\
\text { Xenon propellant }\end{array}$} & $\begin{array}{l}\text { Unclassified - unlimited } \\
\text { STAR Category } 20\end{array}$ \\
\hline 19. Security Classiff. (of this report) & 20. Security Classif. (of this page) & 21. No. of pages \\
\hline Unclassified & Unclassifiec & \\
\hline
\end{tabular}

"For sale by the National Technical Information Service, Springfield, Virginia 22161 
End of Document 